University of Nebraska - Lincoln

DigitalCommons@University of Nebraska - Lincoln

USDA National Wildlife Research Center - Staff Publications
U.S. Department of Agriculture: Animal and Plant Health Inspection Service

August 2006

\title{
AVIAN INFLUENZA IN WILD BIRDS: STATUS AS RESERVOIRS, AND RISKS TO HUMANS AND AGRICULTURE
}

Larry Clark

USDA/APHIS/WS National Wildlife Research Center, clark@metis4u.net

Jeffrey Hall

United States Department of Agriculture, Animal and Plant Health Inspection Service, Wildlife Services, National Wildlift Research Center

Follow this and additional works at: https://digitalcommons.unl.edu/icwdm_usdanwrc

Part of the Environmental Sciences Commons

Clark, Larry and Hall, Jeffrey, "AVIAN INFLUENZA IN WILD BIRDS: STATUS AS RESERVOIRS, AND RISKS TO HUMANS AND AGRICULTURE " (2006). USDA National Wildlife Research Center - Staff Publications. 414.

https://digitalcommons.unl.edu/icwdm_usdanwrc/414

This Article is brought to you for free and open access by the U.S. Department of Agriculture: Animal and Plant Health Inspection Service at DigitalCommons@University of Nebraska - Lincoln. It has been accepted for inclusion in USDA National Wildlife Research Center - Staff Publications by an authorized administrator of DigitalCommons@University of Nebraska - Lincoln. 


\title{
AVIAN INFLUENZA IN WILD BIRDS: STATUS AS RESERVOIRS, AND RISKS TO HUMANS AND AGRICULTURE

\author{
Larry Clark ${ }^{1}$ AND JefFrey Hall
} \\ United States Department of Agriculture, Animal and Plant Health Inspection Service, Wildlife Services, National Wildlifo Research Center, 4101 La Porte Avenue, Fort Collins, Colorado 80521, USA
}

\begin{abstract}
Abstracr.--Influenza A viruses are naturally reservoired in wild bird populations, in which they generally exist as low-pathogenic subtypes. Historically, concern about avian influenza virus (AIV) in wild birds is related to its potential effects on agriculture and human health, and not to health issues of wild bird populations. Several subtypes (primarily H5 and H7) have caused severe outbreaks of disease in domestic bird populations. In some cases, genetic and spatial temporal analyses suggest that these high-pathogenic subtypes may originate in wild bird populations that transmit low-pathogenic forms to domestic birds; after passage in domestic birds, the low-pathogenic subtypes convert to high-pathogenic subtypes. These observations suggest that monitoring AIV activity in wild bird populations, especially waterfowl, may improve risk assessment for poultry producers. Other cases, as exemplified by recent outbreaks of $\mathrm{H} 5 \mathrm{N1}$, suggest that the highly pathogenic subtypes have spilled over into wild populations from domestic production and live-bird markets in Asia. The risk paths (i.e. how the virus gets from waterfowl to domestic birds or vice versa) are not well understood and should be the subject of further research. The number of outbreaks of high-pathogenic AIV is increasing, as is the number of domestic birds that are culled in efforts to contain the spread of infection. These efforts have enormous economic implications. Surveillance has been focused on domestic production of these species. The role of the natural disease ecology of feral swine and quail in generation of avian and human reassortants has not been investigated, but is an area of concern. Direct transmission from birds to humans or other mammals is also possible, as evidenced by human infections caused by H9N2. Because the H5N1 subtype has become endemic to Southeast Asia, and because the human population is immunologically naive, the concern of a pandemic is increased. Although there is little anyone can do about the natural reservoir of AIV in birds, increased information about how the viruses are maintained, transmitted, and moved across the landscape in nature would provide valuable information about agricultural and human-health risk assessment. Received 5 August 2005, accepted 8 January 2006.
\end{abstract}

Resumen. - Los virus de la influenza A se encuentran de manera natural en las poblaciones de aves silvestres, donde por lo general se encuentran como subtipos de baja patogénesis. Anteriormente, la preocupación sobre el virus de la influenza avícola (VIA) en aves silvestres, estaba relacionada con los efectos potenciales en la agricultura y en la salud humana, y no en asuntos sobre la salud de las poblaciones de aves silvestres. Algunos subtipos, especialmente H5 y H7, han causado severos brotes en poblaciones de aves domésticas. En algunos casos, análisis genéticos y de espacio-tiempo han sugerido que estos subtipos altamente patógenos pudieron haberse originado en poblaciones de aves silvestres que transmitieron formas de baja patogénesis a aves domesticas; y al suceder esto, los subtipos de baja patogénesis se convirtieron en subtipos de alta patogénesis. Estas observaciones sugieren que el monitoreo de VIA en aves silvestres, especialmente aves acuáticas, podría mejorar las evaluaciones de riesgo para los productores de aves de corral. En otros casos, como por ejemplo los recientes brotes de H5N1, sugieren que los subtipos altamente patógenos han sido transmitidos a las aves silvestres a través de las aves de corral y la comercialización deanes vivas en los mercados de Asia. Las vías de contagio (por ejemplo, la forma en que el virus pasa de las aves acuáticas a las aves

1E-maii: larry.clark@aphis.usda.gov 


\begin{abstract}
domesticas o viceversa) continúan sin entenderse y deben ser sujetas a futuras investigaciones. El número de brotes de VIA altamente patógenos ha ido en aumento, al igual que el numero de aves domesticas que son seleccionadas con la intención de detectar la infección. Estas selecciones tienen grandes consecuencias económicas. La vigilancia se ha eflocado en la producción domestica de estas especies de aves. E; papel ecológico de enfermedades naturales en puercos salvajes y en codornices en generaciones de recombinantes avicolas y humanos no ha sido investigado, pero es un tema de importancia. La transmisión directa de aves a humanos u otros mamíferos también es posible, como lo demuestran las infecciones humanas causadas por H9N2. Debido a que el subtipo H5N1 se ha vuelto endémico del sureste de Asia, y dado que la población humana es vulnerable inmunologicamente, la preocupación de una pandemia es mayor. Aunque es poco lo que se puede hacer con respecto al hospedero natural de VIA en aves, el aumento de la información, en cuanto como los virus son mantenidos, transmitidos y desplazados a través de el ambiente natural, proveerá información valiosa sobre las evaluaciones de riesgo de la salud humana y de la agricultura.
\end{abstract}

Avian influenza (AI; avian influenza virus = AIV), formally known as fowl plague in wildlife disciplines, has received increasing attention over the years, not only because it represents a serious threat to the welfare of wild bird populations, but because it affects agriculture (i.e. poultry production and trade) and human health. To understand the importance of AI, one must understand the structure of the agent and mechanism of disease within the context of the host range and ecological factors affecting transmission. The present review is intended to bridge the various scientific disciplines toward this end. We review the etiology of influenza $A$ viruses, their host ranges, and the risk paths from wild birds to agriculture to humans, in an effort to emphasize inter-relationships between avian ecology, wildlife disease ecology, agriculture and veterinary medicine, and human epidemiology.

Avian influenza A virus. - Influenza viruses are members of the family Orthomyxoviridae (the Greek root myxo-, mucus, attests to the respiratory ramifications of disease caused by these viruses). These viruses are further classified, on the basis of antigenic properties of the nucleoprotein and matrix proteins, as influenza $A, B$, or $C$. Influenza A viruses have been isolated from various animal species, including birds, pigs, horses, and humans, whereas influenza $B$ and $C$ viruses a re primarily human pathogens (Fields et al. 1996). Influenza A viruses have much more variable surface glycoproteins than either $B$ or $C$ viruses, yet phylogenetic analyses show that influenza $A$ and $B$ viruses are more closely related to each other than to influenza $C$.

Only type $\mathrm{A}$ influenza viruses are known to cause natural infection in birds (Webster et al.
1992). Low-pathogenic forms of AIV (LPAIV) are most common in wild birds, in which they do not appear to cause disease. When LPAIV infects poultry, mild disease may become apparent. Although egg production may be affected, the disease is not considered severe. There is little mortality and, from a trade and production viewpoint, most low-pathogenic forms of $\mathrm{AI}$ are not considered reportable diseases by the Organization Internationale Epizooties (OIE). By contrast, high-pathogenic AIV (HPAIV) forms rarely occur in wild birds and are considered primarily a problem of the poultry industry (Suarez 2000). High-pathogenic AIV causes high mortality in infected flocks (often $100 \%$ ) and can lead to severe direct and indirect economic losses and international trade sanctions. High-pathogenic AI is considered an OIE reportable disease.

If wild birds are primarily a reservoir of LPAIV, and only HPAIV is of concern to the poultry industry, why do agriculture and public-health workers care about the extent of AIV infection in wild birds? The answer lies in the high mutability of the virus and its propensity to exchange genetic material between subtypes; reassortants are the basis for the formation of new subtypes. One consequence of this process is that LPAIV can be transformed into HPAIV through adaptation and passage in intermediate hosts. Genetic analyses of HPAIV have supported the notion of a wildlife origin of the viruses. As a consequence, there is increasing recognition that surveillance of AIV in wild bird populations may provide valuable information for predicting the probability of future outbreaks of influenza in poultry flocks and humans (FAO 2004a). 
Agricultural concerns. - High-pathogenic AI was not described in the poultry industry until 1959 (Alexander 2000). Since then, the number of outbreaks has increased exponentially (Fig. 1 ), as has the amount of poultry taken out of the economy because of disease effects and culling of infected flocks (Fig. 2). The economic and sociological consequences of HPAI and LPAI outbreaks are enormous (FAO 2004b, Hall 2004, Weiss and McMichael 2004). For example, during the 1983-1984 AI outbreak in poultry flocks in Pennsylvania, >17 million birds, valued at $\$ 55$ million, were destroyed in efforts to contain the disease. Cleanup cost an additional $\$ 8$ million. Of the total $\$ 63$ million in losses, $\$ 40$ million was ultimately paid by taxpayers. Additional costs were borne by consumers. Because of the reduced availability of poultry, retail prices for poultry food products increased by $\$ 349$ million over the ensuing six-month period (Hahn and Clark 2002). Accounting for inflation, the total losses in 2003 dollars would have been $\$ 969$ million (Clark 2003). Not included in these estimates are costs of trade embargoes imposed on U.S. exports of poultry products. Recent outbreaks of subtypes H7N7 in The Netherlands and $H 5 \mathrm{~N} 1$ in Thailand and Vietnam resulted in agricultural losses estimated at $\$ 348$ million, $\$ 880$ million, and $\$ 120$ million, respectively (Fouchier et al. 2005). Additional examples of the economic costs of AI infection have been documented in Asia, Australia, Italy, the United States, and elsewhere (Poss et al. 1981, Westbury 1997, Davison et al. 1999, Capua and Alexander 2004, FOA 2004b, Hall 2004).

Human health concerns. - Human influenza viruses cause epidemics every year (Snacken et al. 1999, Monto 2000). Of particular concern are events that led up to the human pandemics of 1918, 1957, 1968, and 1972 and the role birds may have had in the generation of new viral subtypes. The magnitude of these pandemics is sobering; the pandemic of 1918 killed 20-50 million people (Reid et al. 1999). Understanding the role of wild birds in the disease's epidemiology, and how human viral reassortants arise, is important for planning and preparation for future pandemics (Scholtissek et al. 1978, Reid et al. 1999). Avian influenza virus surface glycoproteins change by antigenic drift, resulting in genetic variants of the same subtype that may be able to evade host immune pressure. Genomic

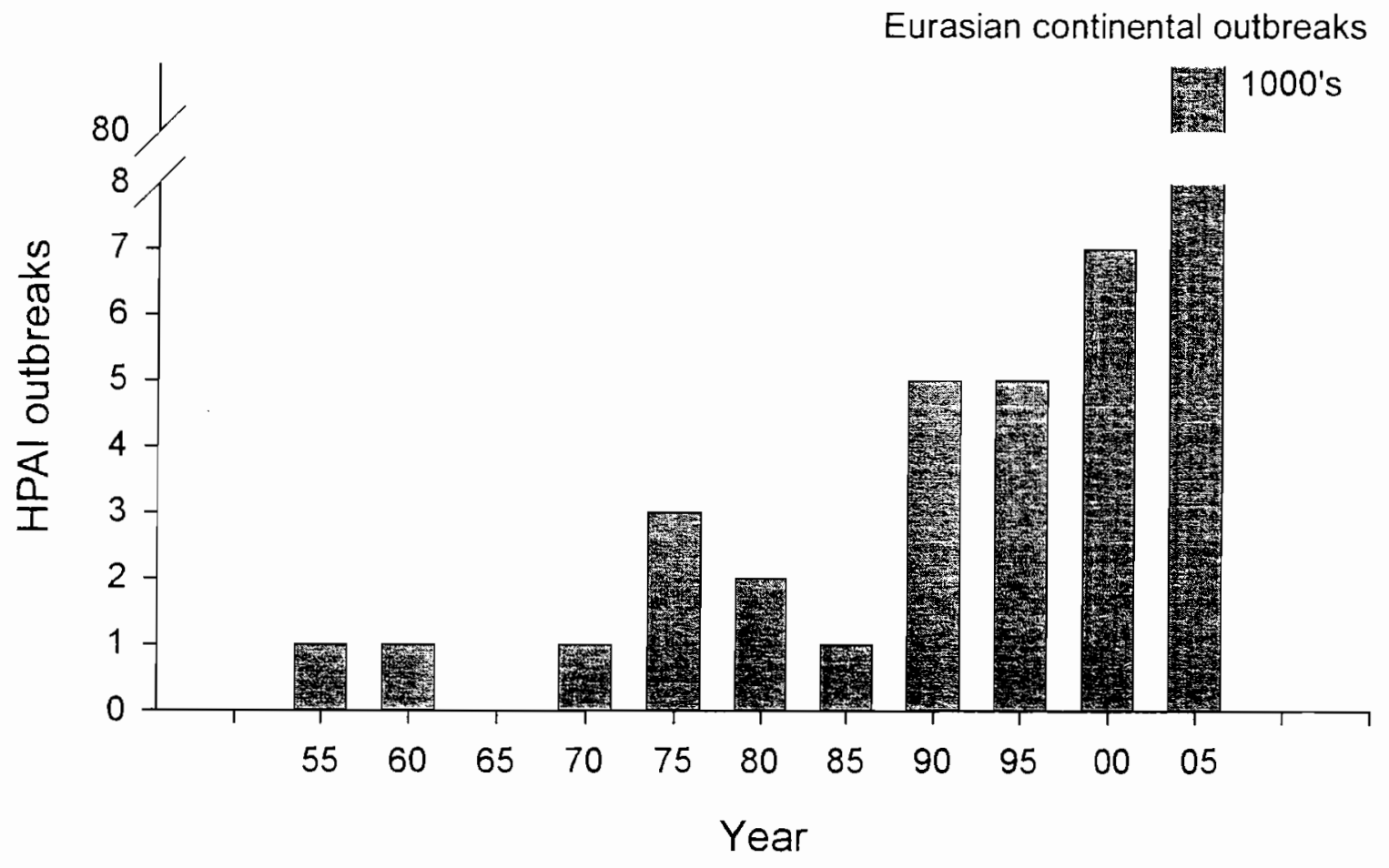

FIG. 1. Number of primary global outbreaks of high-pathogenic avian influenza (HPAI; H5 and H7 subtypes) in poultry flocks as a function of time (1955-2000). Data adapted from Alexander (2000) and Capua and Alexander (2004). 


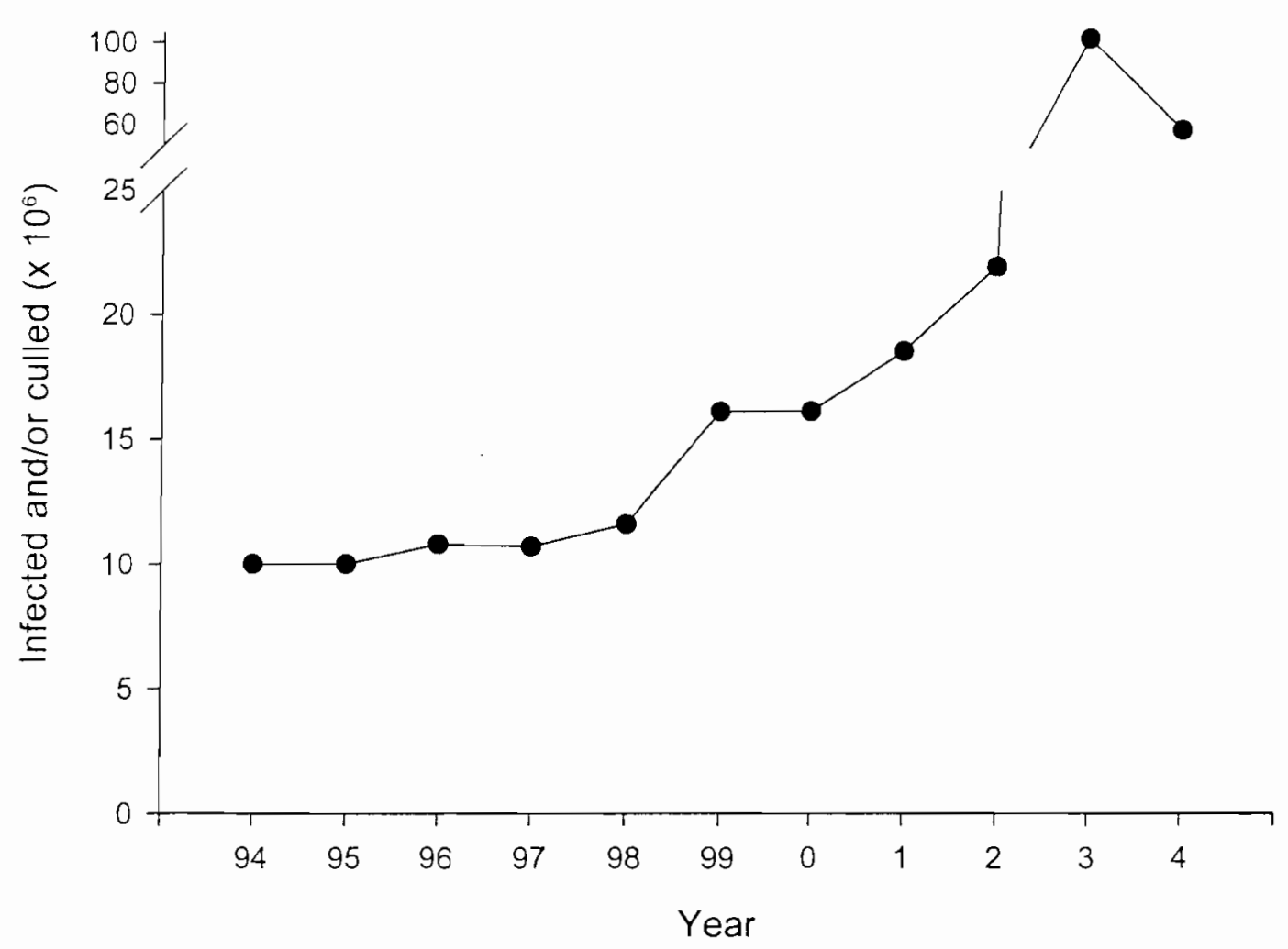

FIG. 2. Number of poultry infected, worldwide, with high- and low-pathogenic avian influenza (HPAI and LPAI; H5 and H7 subtypes) as a function of time (1994-2004). Data adapted from Capua and Alexander (2004).

information from recent human pandemics indicates that introduction of avian gene segments into the human influenza virus genome has often occurred. Evidence suggests that avian and human influenza viruses co-infecting other mammalian hosts (e.g. swine [Sus spp.]) reassort within the host to form deadly new human pathogenic subtypes. If these subtypes also acquire the capability of efficient transmission between humans, the scenario for a pandemic is complete. Of concern recently is the origin of a highly virulent form of AIV, H5N1, which is responsible for the ongoing outbreaks of $\mathrm{AI}$ in Asia, which began in 1997 (Shortridge et al. 1998).

Integration of information. - It is now apparent that waterfowl are the primary reservoir of AIV, and that viruses circulating in wild bird populations are the source of AIV subtypes of concern to the poultry industry and to public health. Tracking potential paths for movement of AIV genomic material through the agriculture landscape to humans is a critical first step in planning for agricultural biosecurity and human health risk-assessment and vaccine development (FAO 2004a).

\section{Structure and Genome Organization}

Influenza viruses are small $(80-120 \mathrm{~nm}$ in diameter), enveloped viruses. The lipid envelope is studded with the viral proteins HA, NA, and $\mathrm{M}_{2}$. Influenza $A$ virus genomes comprise eight strands of negative polarity, single-stranded RNAs that are numbered according to length. The specific functions of the 10 individual gene products are reviewed in depth elsewhere (Lamb 1989, Webster et al. 1992, Baigent and McCauley 2003); here, we only briefly describe the roles of the viral proteins. The three largest RNA segments (RNA 1,2,3) code for subunits of the viral RNA polymerase (PB2, PB1, and PA, respectively) and are responsible for transcription and amplification of the viral genome. A "cap-snatching" function of the viral polymerase, where the 5' methylated ends of cellular mRNAs are cleaved and used as primers for transcription of viral mRNAs, is a unique feature of these viruses.

RNA 4 codes for the hemagglutinin (HA) protein. An integral membrane protein, $\mathrm{HA}$ is the major antigenic protein in influenza virions. It is involved in receptor binding to host cells and 
membrane fusion between the virion and host cell. Hemagglutinin requires post-translational processing by host-derived proteases before becoming functional and enabling virions to be infectious. Insertion or substitution of additional basic residues at the precursor cleavage site broadens the tissue tropism of the virus and seems to be an important difference between high-and low-pathogenicity forms of influenza (Alexander 2000). Hemagglutinin is highly variable and is a major pathogenicity determinant. Driven by selection from the host's immune system, HA genes can be $>30 \%$ divergent in the amino acid sequences. Currently, there are 16 serologically distinct HA subtypes (HA1HA16), most of which are avian-specific.

The nucleoprotein (NP) is encoded by RNA 5 . This protein binds to viral RNA, is abundant in the mature virion, and is an important target of the immune response. The accumulation of NP is involved in switching from transcription to viral genome amplification by the viral polymerase.

Neuraminidase (NA), another integral membrane protein encoded by RNA 6, is a major pathogenicity determinant. Neuraminidase enzymatically cleaves sialic acid residues and is involved with virus budding, release, and spread; receptor binding; and host-range determination. Neuraminidase is another important immunological target and is also highly variable, with nine subtypes (NA1-NA9) circulating in nature.

Both RNA 7 and RNA 8 are bicistronic by alternative splicing, yielding two proteins each. RNA 7 codes for the matrix protein M1, the most abundant protein in the mature influenza virion. This protein surrounds the viral nucleoprotein in the virion and plays a key role in virus assembly and transport of viral ribonucleoprotein to and from the nucleus. Matrix protein M2, also from RNA7, is a membrane protein believed to function as an ion channel. It is present in large quantities in infected cells, and in much smaller amounts in virions, and appears to be involved in $\mathrm{pH}$ control during viral uncoating and maturation.

Nonstructural proteins NS1 and NS2 are derived from RNA 8. The NS1 protein is involved in regulation of viral RNA splicing, translation, and polymerase activity. It also shuts down host-cell mRNA translation and some host antiviral responses. The NS2 protein appears to be involved in the export of viral ribonucleoproteins from the nucleus.
Evolution

RNA viruses have the capacity to evolve rapidly. Viral RNA polymerases typically have error rates in the neighborhood of $1 \times 10^{-1} / \mathrm{nt} /$ replication (Drake 1993) and - considering the lack of proofreading mechanisms, the large population sizes, and short generation times-vast arrays of mutants are constantly and quickly generated. Selection and stochastic events then exert influence on the population of mutants, increasing or decreasing their frequencies (Domingo and Holland 1994, Domingo et al. 1996).

In the case of influenza $\mathrm{A}$, host immune systems exert considerable selective pressure on viral genomes to produce variants that can evade detection. The genome accumulates point mutations in a stepwise fashion. This is especially evident with the exposed envelope proteins $\mathrm{HA}$ and $\mathrm{NA}$, which are the major targets for neutralizing antibodies in the virion. This process is called antigenic drift and, over time, can lead to large differences in genetic sequences.

If a host becomes infected by more than one influenza virus, the potential for genetic recombination occurs. This would result in one or more hybrid molecules having characteristics potentially very different from those of either parent molecule. Apparently, this occurred before 1918, precipitating the Spanish flu pandemic, which killed 20-50 million people worldwide. The HA gene isolated from flu victims buried in the permafrost of Alaska contains sequences from both human and swine lineages, which indicates that a homologous recombination event occurred before 1918 (Gibbs et al. 2001, Fanning et al. 2002), creating a more virulent virus. "Antigenic shift" is the term used to describe these potentially drastic changes in virus biology, and the generation of new pandemic subtypes of influenza is a virtual certainty.

Antigenic shift can also result from sequence insertions or deletions that alter the life cycle of the virus (e.g. insertion of additional basic residues at the cleavage site in $\mathrm{HA}$ that alter the pathogenicity of the virus). Viruses can be promiscuous and are known to acquire sequences from host mRNA pools or from other viruses and pathogens. For example, Khatchikian et al. (1989) recovered an isolate of influenza with an insertion of 54 nucleotides from the host's 28S ribosomal RNA into the HA gene. This virus showed increased cleavability and pathogenicity. 
An influenza mutant, with defective NA function resulting from a 24-amino-acid deletion, repaired itself and regained complete function by inserting portions of PB1, PB2, or NP genes into the NA gene (Mitnaul et al. 2000).

Viruses with multicomponent genomes have an additional method for generating genetic diversity. If a cell is infected with two different influenza viruses, the progeny virions may contain a mixture of RNAs from the two parental subtypes. This "shuffling of the deck" is called reassortment and has occurred frequently over the years. This process has been implicated in the 1957 and 1968 influenza pandemics (Baigent and McCauley 2003).

Humans are typically not directly infected by avian lineages of influenza (Shortridge et al. 1998). Avian influenża genomes are believed to be evolutionarily more stable than human influenza subtypes. However, swine have been implicated as genetic "mixing vessels," because they are capable of being infected by both avian and human influenza subtypes (Castrucci et al. 1993, Ito et al. 1998). The fact that swine often reside in proximity to both domestic birds and humans creates a scenario ripe for the creation of new, potentially pandemic, hybrid subtypes of influenza.

\section{NOMENClature}

Influenza viruses are typically categorized on the basis of the main pathogenicity genes they contain, HA and NA. As mentioned above, there are 16 HA subtypes and 9 NA subtypes, and an isolate of influenza with HA-7 and NA-4 would be labeled "H7N4." All HA and NA subtypes are found in birds, but most do not replicate efficiently in humans, though all HA subtypes can replicate to some degree in mammalian model systems (Hinshaw et al. 1981). Historically, human disease has been associated mainly with $\mathrm{H} 1, \mathrm{H} 2$, and $\mathrm{H} 3$ subtypes. However, subtypes $\mathrm{H} 5, \mathrm{H} 7$, and $\mathrm{H} 9$ have recently been implicated in human disease. This represents a disturbing shift in AI infectivity for humans. The primary subtypes of NA in human influenza are N1, N2, and (recently) N7 (Biagent and McCauley 2003).

\section{Pathogenesis}

Symptoms. - Avian influenza is usually a mild or even inconsequential disease in wild birds, with only a few cases of mortality and overt disease symptoms reported (Becker 1966, Ellis et al. 2004a). In domestic species, signs of AI are variable among species and breeds of birds, ranging from asymptomatic to respiratory, enteric, reproductive, or nervous-system manifestations. For LPAI, the first signs of disease are decreased food consumption and lowered egg production. Other symptoms may include coughing, sneezing, ruffled feathers, swollen heads, depression, and diarrhea. For some subtypes of AI, the only evidence of flock infection may be seroconversion for antibody against AI. For HPAI, the incubation period is three to five days. Birds experience a rapid onset of fever, become lethargic, and lose appetite. Death can occur within a few hours after symptoms appear (Swayne and Suarez 2000).

Molecular mechanisms. - Unlike classic disease agents, influenza viruses have to alter their genetic makeup to change their host range. The basic reasons for this involve (a) the specificity of HA binding to the cellular receptor and (b) the ability of NA to cleave different linkages of sialic acid. In avian influenza, HA specifically binds to sialic acid residues that are $\alpha$ 2,3-linked to galactose, and NA specifically cleaves sialic acid at those residues. The abundance and types of these receptors on host cells define whether the virus can infect the animal. Sialic acid $\alpha 2,3$ residues are mainly located on the surfaces of cells in gastrointestinal tracts of birds, which explains the tissue tropism of influenza in this taxon (Slemons and Swayne 1995). However, some variation in tissue tropism among avian species and AI subtypes exists, with some species having an abundance of receptors in the respiratory epithelium as well (Liu et al. 2003).

The HPAI viruses are restricted to the $\mathrm{H} 5$ and $\mathrm{H} 7$ subtypes, though not all viruses of these subtypes cause HPAI. The remaining viruses are considered to cause LPAI. The HA precursor of the main functional $\mathrm{HA}$ glycoprotein requires cleavage by host proteases before virus particles are infectious. LPAI viruses are limited by host proteases (e.g. trypsin and trypsin-like enzymes). As a consequence, replication is restricted to sites where these enzymes occur (i.e. intestinal and respiratory epithelium). Virulent viruses are cleavable by ubiquitous proteases, which allows the viruses to replicate throughout the animal, damaging vital organs and tissues and resulting in disease and death (Rott 1992). Comparison of amino acid 
sequences of HPAI and LPAI at the HA cleavage site show that LPAI viruses have two basic amino acids, at positions 1 and 4 for subtype $\mathrm{H} 5$ and at positions 1 and 3 for subtype $\mathrm{H} 7$. High-pathogenic AI viruses possess multiple basic amino acids adjacent to the cleavage site. This results in a motif cleavable by ubiquitous proteases (Senne et al. 1996). Several instances of conversion from LPAI to HPAI have been documented in poultry (Mexico: Perdue et al. 1997; Chile: Suarez et al. 2004).

Avian influenza isolates do not efficiently replicate in humans and other mammals, and they usually need to adapt to mammalian hosts before they can become an agent of disease. For example, in humans, sialic acid residues in the trachea are $\alpha$ 2,6-linked to galactose and, thus, are not efficiently bound and cleaved by avian HA and NA. However, pigs are permissive hosts to both avian and human influenza viruses. Pigs have sialic acid in both linkages and, thus, can be productively infected by both avian and human influenza viruses, which creates the potential for co-infection, reassortment, and adaptation of avian influenza into a human pathogen. Interestingly, quail (Coturnix coturnix japonicus) also have sialic acid in both linkages and, thus, may also be an important host, sustaining multiple infections and providing opportunity for AI reassortment and adaptation into a human pathogen (Liu et al. 2003; Perez et al. 2003a, b).

\section{Modes of Transmission}

The route of exposure can be direct or indirect. In birds, AIV is spread primarily by fecaloral routes. The AIV replicates in intestinal epithelial tissue of birds and is shed cloacally 2-14 days postinfection ( $\mathrm{Lu}$ and Castro 2004). Infected birds shed virus into water in feces, and other animals become infected by drinking the contaminated water (Roy et al. 1983, Lai and McPhillips 1999). The AI virus is relatively stable under normal aquatic environmental conditions, but persists longer and maintains infectivity with cooler temperatures. Viable virus was recovered from experimentally contaminated water after 220 days at $18^{\circ} \mathrm{C}$ and after 90 days at $26^{\circ} \mathrm{C}$. Duration of infectivity decreased with increasing salinity and $\mathrm{pH}$ (Stallknecht et al. 1990a, b, c). Field studies have shown that the virus remains viable in ponds even after freezing over winter and can act as a source of re-infection in waterfowl (Ito et al. 1995, Kida 1997). Because of the persistence of the virus, domestic poultry are at risk any time they share a common water source with wild waterfowl. Contamination of water sources may also occur via surface runoff from contaminated sites (e.g. fields fertilized with contaminated manure) or by intrusion of contaminated surface water into groundwater (Halvorson et al. 1985). Thus, any use of contaminated manure from poultry operations for fertilizing fields and crops can act as a source of infections. However, even though litter and other contaminated solids are highly infectious, AIV is less stable in litter and compost than in water. In chicken (Gallus domesticus) manure, AIV becomes inactivated after a week, owing to heat of fermentation, the $\mathrm{pH}$ of the environment, desiccation, or a combination of these factors (Senne et al. 1994, Lu et al. 2003). Aerosolized fecal dust also can infect animals via oral and respiratory routes, though the latter is a less efficient mode of infection in birds.

\section{HOST RANGE}

Avian influenza virus occurs widely in wild birds (Fig. 3), having been isolated from $>90$ species distributed among 12 orders (reviewed in Stallknecht and Shane 1988, Stallknecht 1998).

Waterfowl-Among birds, wild waterfowl are the largest reservoir of haemagglutinin and neuraminidase subtypes of influenza A viruses, with $16 \mathrm{H}$ and $9 \mathrm{~N}$ subtypes having been detected in almost all combinations (de Boer et al. 1992). However, subtype dominance across North American studies suggests some degree of AIV stability in waterfowl. The most common HA subtypes detected in waterfowl are $\mathrm{H} 3, \mathrm{H} 4$, and $\mathrm{H6}$, whereas the most common NA subtypes detected are N2, N6, and N8 (Sharp et al. 1993, Hanson et al. 2003). The most common combination of HA and NA subtypes isolated from waterfowl are $\mathrm{H} 3 \mathrm{~N} 8, \mathrm{H} 4 \mathrm{~N} 6, \mathrm{H} 4 \mathrm{~N} 8$, H6N2, H6N8, and H9N2 (Hanson et al. 2003, Krauss et al. 2004). The $\mathrm{H} 5$ and $\mathrm{H} 7$ subtypes that cause disease in poultry and humans are detected less frequently, have lower prevalence $(1-8 \%)$, and apparently do not persist in wild waterfowl populations, which suggests that waterfowl may not be important reservoirs for these subtypes (Kawaoka et al. 1988, Sharp et al. 1993). However, in later studies, Hanson et al. (2003) found a relatively higher prevalence of 


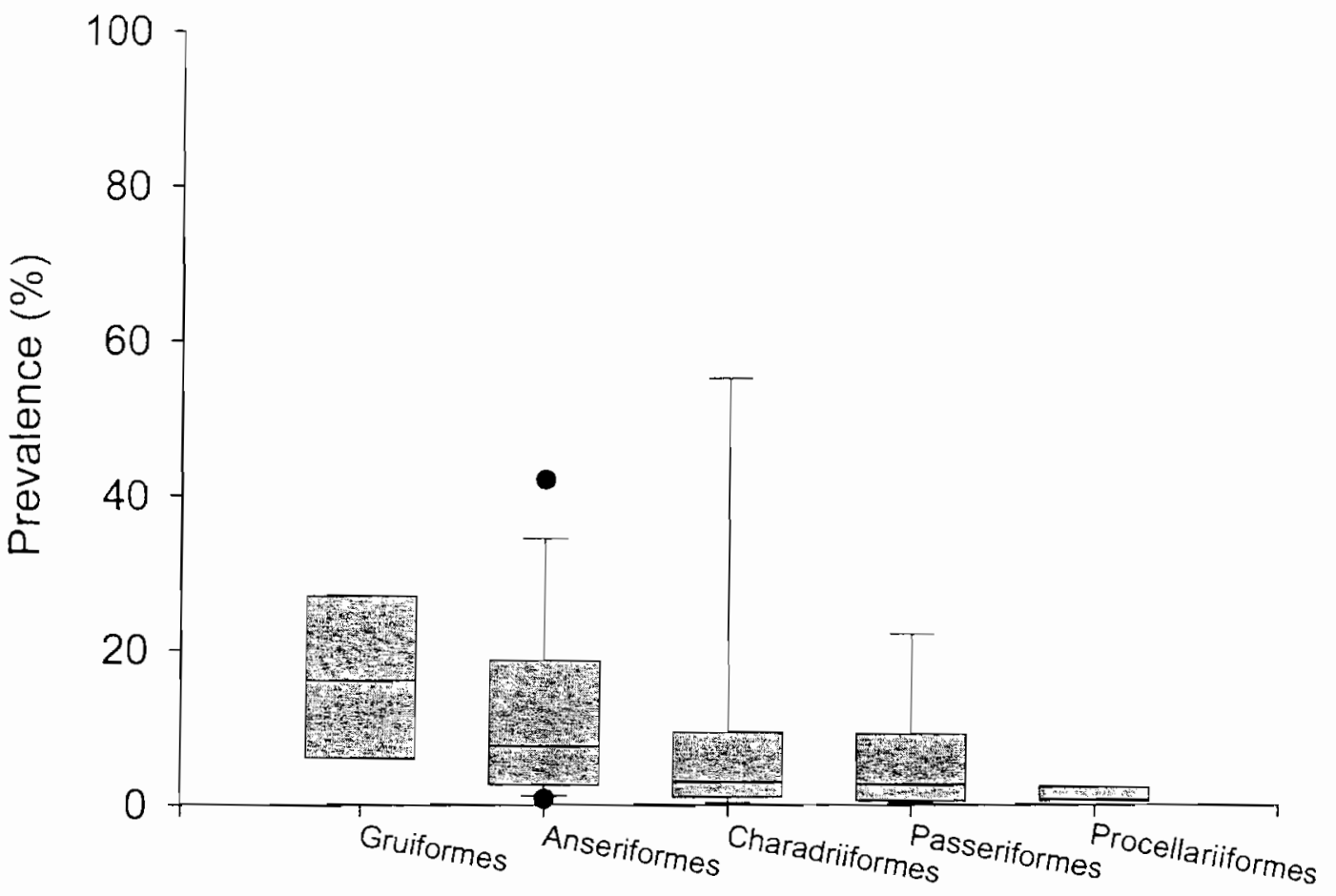

FIG. 3. Prevalence of avian influenza subtypes found in wild birds. Horizontal lines depict median, boxes encompass 25 th -75 th percentiles, capped bars encompass 10 th-90th percentiles, and dots encompass 5 th -95 th percentiles. Number of species (S) and studies (N) represented include Gruiformes $(S=3, N=5)$; Anseriformes $(S=26, N=37)$; Charadriiformes $(S=13, N=13)$; Passeriformes $(S=11, N=3)$, and Procellariiformes $(S=1, N=$ 3). Data adapted from Stallknecht and Shane (1988).

$\mathrm{H} 5, \mathrm{H} 7$, and $\mathrm{H} 9$ subtypes (20\%) in a multiyear study conducted in Minnesota. Over the past 30 years, only 30 studies have characterized AIV subtype distribution and prevalence in North America, and most of these studies were conducted between 1970 and 1980. Thus, there is little basis for objectively evaluating whether differences in subtype prevalence and distribution among studies represent local sampling effects or changes in ecological disease dynamics that have occurred over time (Hanson et al. 2003). Determining the underlying cause for the differences is critical for developing an objective risk assessment for the role that waterfowl may play as a reservoir of AIV subtypes of animal and human health concern.

Besides the characterization of common subtypes, other patterns of AIV prevalence exist. Prevalence of AIV in wild waterfowl populations varies as a function of space (Fig. 4), time (Fig. 5), and age structure of the host population (Hinshaw and Webster 1982). For waterfowl, the peak AIV transmission occurs during premigration staging in late summer, with the highest incidence of virus detected in juvenile birds (Hinshaw and Webster 1982, Hinshaw et al. 1985, Alfonso et al. 1995). Prevalence of virus is lower during the winter and on wintering grounds. The higher prevalence of AIV in waterfowl during late summer is consistent with epidemiological susceptible, infected, recovery (SIR) models. Recruitment of immunologically naîve animals via reproduction occurs throughout spring and summer, and these animals aggregate by late summer. These conditions promote efficient transmission of the virus. Spatial variability in the distribution of infected ducks may result from less-than-complete concordance between contaminated water sources and gathering points for naïve waterfowl, or from the stochastic encounter probability between infected and naïve animals.

Gulls and shorebirds. - Subtypes prevalent in waterfowl are rare or absent in shorebirds and gulls (Charadriiformes). However, half the subtypes common in charadriiforms in spring and fall have the potential to infect waterfowl, which indicates that charadriiforms are a reservoir of AIV for waterfowl, providing opportunities for reassortment (Kawaoka et al. 1988). In 


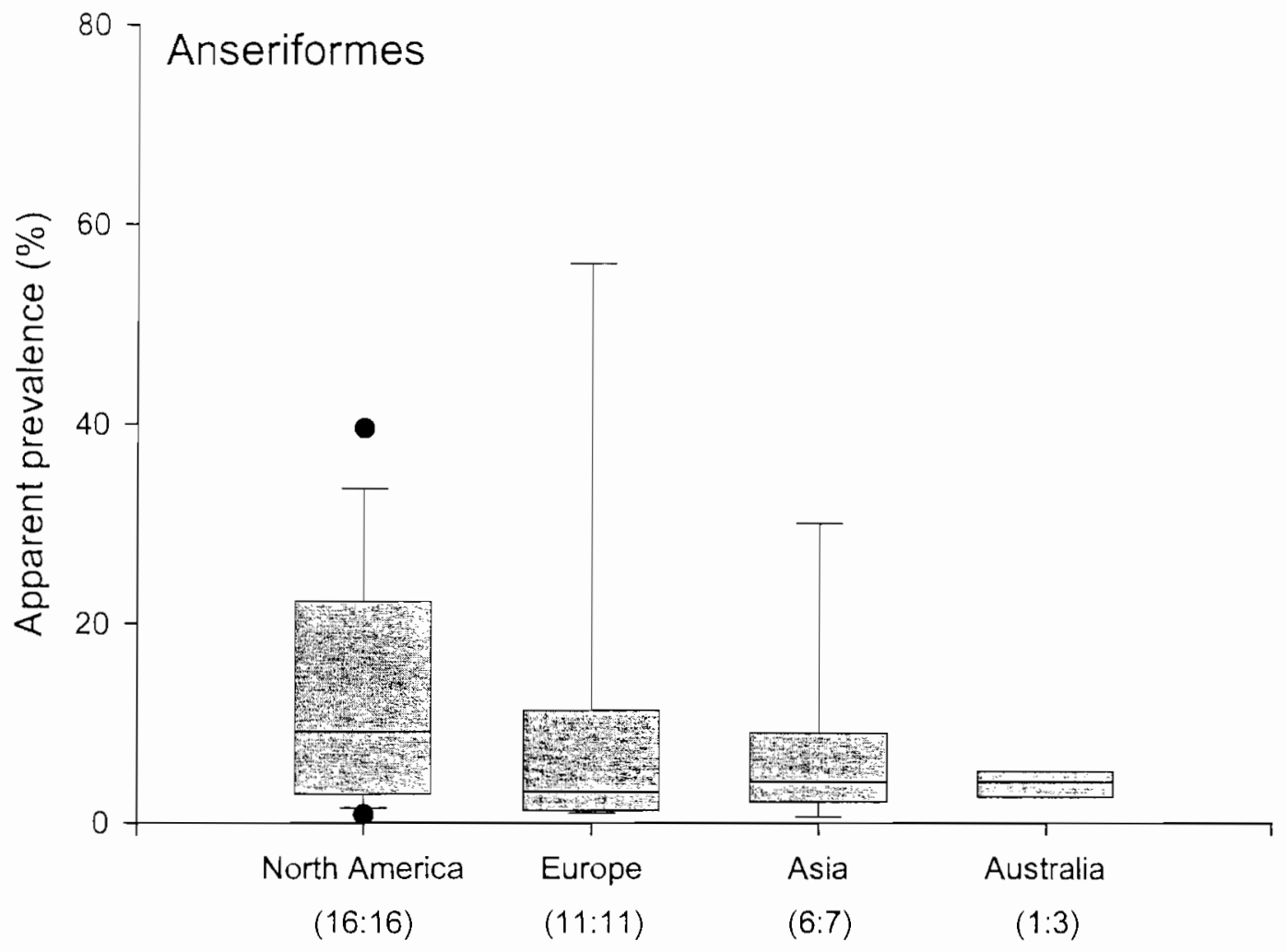

FiG. 4. Prevalence of avian influenza subtypes in waterfowl surveys as a function of continental sampling location. Horizontal line depicts the median, boxes encompass the 25th-75th percentiles, capped lines encompass the 10th-90th percentiles, and dots encompass the 5th-95th percentiles. Numbers in parentheses indicate numbers of studies and of species surveyed, respectively. Data adapted from Stallknecht and Shane (1988).

a 16-year study, Krauss et al. (2004) reported that $\mathrm{H} 3$ and $\mathrm{H} 11$ were the most common $\mathrm{HA}$ subtypes $(33 \%)$ detected in shorebirds, whereas $\mathrm{N} 2, \mathrm{~N} 4, \mathrm{~N} 8$, and $\mathrm{N} 9$ were the most commonly detected NA subtypes.

Other wild birds. - Little emphasis has been placed on surveillance for avian influenza in other groups of birds, though AIV has been detected in a wide range of avian hosts (Stallknecht and Shane 1988). The prevalence of avian influenza subtypes in 12 species of loons (Gaviidae), grebes (Podicipedidae), cormorants (Phalacrocoracidae), ibises (Threskiornithidae), petrels (Procellariidae), Galliformes, and coots (Rallidae) was between $0.2 \%$ and $32.0 \%$ (Boudreault et al. 1980, Iftimovici et al. 1980, Mackenzie et al. 1984). Among passerines, the reported prevalence for 24 species fell between $0.4 \%$ and $10.0 \%$ (Isachenko et al. 1974; Lipkind et al. 1979, 1980; Amin et al. 1980; Boudreault et al. 1980; Romvary et al. 1980). A better monitoring effort to determine the reservoir potentials of the different orders of wild birds is clearly needed.
Cats._Domestic cats (Felis catus) are generally considered resistant to influenza (Paniker and Nair 1970, 1972; Hinshaw et al. 1981). However, during the 2003 H5N1 poultry outbreak in Thailand, two tigers (Panthera tigris) and two leopards ( $P$. pardus) became infected with $\mathrm{H} 5 \mathrm{~N} 1$ and died. The AIV isolates had a high degree of homology to the avian outbreak subtype (Keawcharoen et al. 2004). Domestic cats experimentally infected with the H5N1 circulating in Asia developed disease, excreted virus, and transmitted virus to sentinel cats, which indicates a virulence shift of this subtype for mammals (Kuiken et al. 2004). More generally, given their association with rodent control in poultry production and their unrestricted access throughout such facilities, cats should be considered a biosecurity risk for transmission and mechanical carriage of AIV. Cats may also provide an opportunity for AIV to adapt to mammals, thus increasing risk of successful human infections.

Swine-As previously discussed, pigs are considered important mixing vessels for AIV. Having cellular receptors for AIV in common 


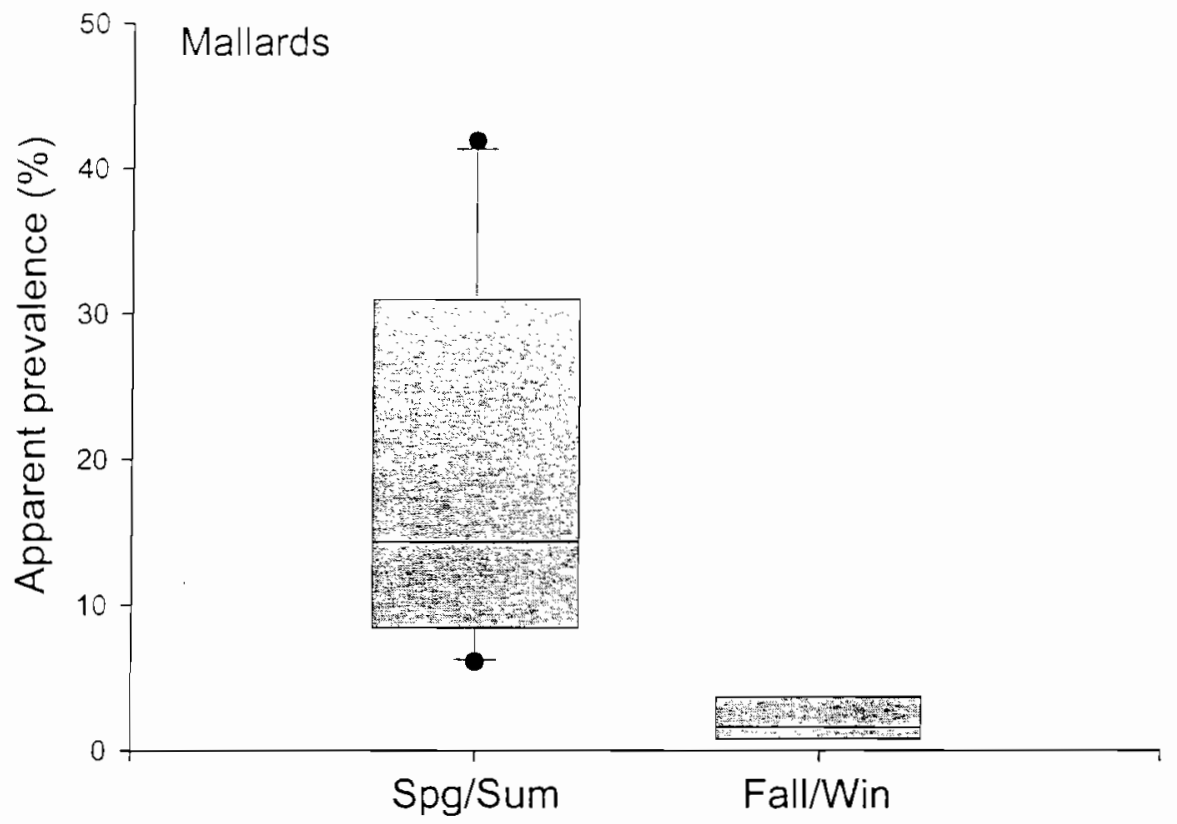

FIG. 5. Prevalence of avian influenza in Mallards in North America as a function of season. Horizontal line depicts the median, boxes encompass the 25 th-75th percentiles, capped lines encompass the 10th-90th percentiles, and dots encompass the 5th-95th percentiles. Spg/Sum is defined as April-September; Fall/Win is defined as October-March. Data encapsulated in the Spg/Sum surveys include a total of 6,023 Mallards sampled (range: 46-2,899) in nine studies. Data encapsulated in the Fall/Win surveys include a total of 1,171 Mallard samples (range: 43-669) in six studies. Data adapted from Stallknecht and Shane (1988).

with birds and mammals, pigs provide opportunities for co-infection with avian and mammalian, including human, subtypes of influenza (Wright et al. 1992, Kida et al. 1994). Reassortment of the virus subtypes can then occur, with creation of chimeric progeny viruses containing avian and mammalian genetic elements (Ito et al. 1998).

Influenza was first found in pigs in 1930. In North America, most isolates were "classical swine influenza" H1N1 until the mid-1990s (Olsen 2002); since then, seroprevalence in swine of $\mathrm{H} 3 \mathrm{~N} 2, \mathrm{H} 1 \mathrm{~N} 2$, and (more recently) H4N6 isolates has dramatically increased (Hinshaw et al. 1978, Chambers et al. 1991, Karasin et al. 2000, Olsen et al. 2000). Recent serosurveys have revealed exposure rates in swine as high as $28 \%$ for the HiN1 subtype (Olsen et al. 2000, Webby et al. 2000). The ability of swine to become infected with avian-derived influenza is illustrated by the $\mathrm{H} 4 \mathrm{~N} 6, \mathrm{H} 3 \mathrm{~N} 3$, and H1N1 subtypes that originated in ducks (Karasin et al. 2000). Evidence of the ability of swine to act as reassorting vessels is provided by the $\mathrm{H} 3 \mathrm{~N} 2$ isolates circulating in North American pigs that are triple reassortants containing $\mathrm{HA}, \mathrm{NA}$, and $\mathrm{PB1}$ of human-influenza origin; $\mathrm{M}, \mathrm{NP}$, and NS genes of classical swine influenza; and PA and PB2 genes of AI origin (Zhou et al. 1999). Host range shifts are not unidirectional. Recently, a H3N2 variant swine virus has become adapted to birds and has infected domestic turkey (Meleagris gallopavo domesticus) flocks in several locations in the United States (Choi et al. 2004).

Pigs in Asia seem to be especially important in host range shifts, perhaps because of husbandry practices whereby pigs, domestic birds, and humans have more direct contact than elsewhere (Webster et al. 1977). Avian influenza isolates have often become capable of infecting pigs or have provided genetic elements for reassortments, some of which have been, and will be, capable of pandemic potential. For example, transmission to pigs of the avian subtype H9N2 was detected in 2000 under conditions of cocirculation of the human H3N2 within pigs. Genetic analysis suggested repeated transmission from birds to pigs.

Overlooked when considering reassortment opportunities in the intensive-agriculture environment of Asia is the natural interaction of wild birds (migratory waterfowl in particular) and feral swine. Although the human interaction 
with these animals may be limited to hunters (Robson et al. 1993), this is still a risk path for exposure to novel reassortant subtypes of AIV. Moreover, the degree to which feral and domestic swine interact is often unexamined (Gipson et al. 1999); such interactions would provide a direct link between wildlife, peridomestic or feral animals, domestic animals in the farm environment, and humans. The importance of these risk paths has yet to be determined.

\section{ZOOGEOGRAPHY}

Nine major flyways are recognized for northern migrants: four each in Eurasia and in the Americas (Fig. 6). By definition, the avian migratory flyways represent tendencies of birds to restrict their movements within broad geographic bounds. This restricted movement is reflected in the antigenic structure of AI. North American and Eurasian lineages of AIV in migratory birds are largely distinct (Donis et al. 1989, Garcia et al. 1997, Makarova et al. 1999, Banks et al. 2000).

In the Americas, all four flyways funnel through Central America and the Caribbean, presenting an opportunity for latitudinal and longitudinal mixing of circulating AIV. Although there is a fair amount of information on the host range of AIV subtypes circulating in waterfowl in North America, little is known about the distribution of AIV among wild birds in South America. A recent outbreak of LPAIV H7N3 in poultry in Chile, which apparently converted to an HPAIV form, provided a glimpse into the relatedness of this subtype with other AIV clades. The LPAIV had an HAO cleavage site similar to those of other lowpathogenic $\mathrm{H7}$ viruses, but the HPAIV form had a 30-nucleotide insert, which likely occurred by recombination between the HA and nucleoprotein genes of the LPAI, resulting in a virulence shift. This pattern is different from patterns seen in other known HPAIV. Sequence comparisons showed that the Chilean virus was distinct from other AIV and represents a distinct South American clade (Suarez et al. 2004).

Between 1959 and 2001, there have been 18 primary outbreaks of HPAI in poultry (10 H7 and 8 H5; Alexander 2001). Five outbreaks have occurred in the British Isles, five in Australia, three in Europe, and one each in Pakistan, Hong Kong, Canada, United States, and Mexico. No AIV has been isolated in South America. The lack of AIV in South America is surprising, given the extensive migratory bird exchange between North and Central America and parts

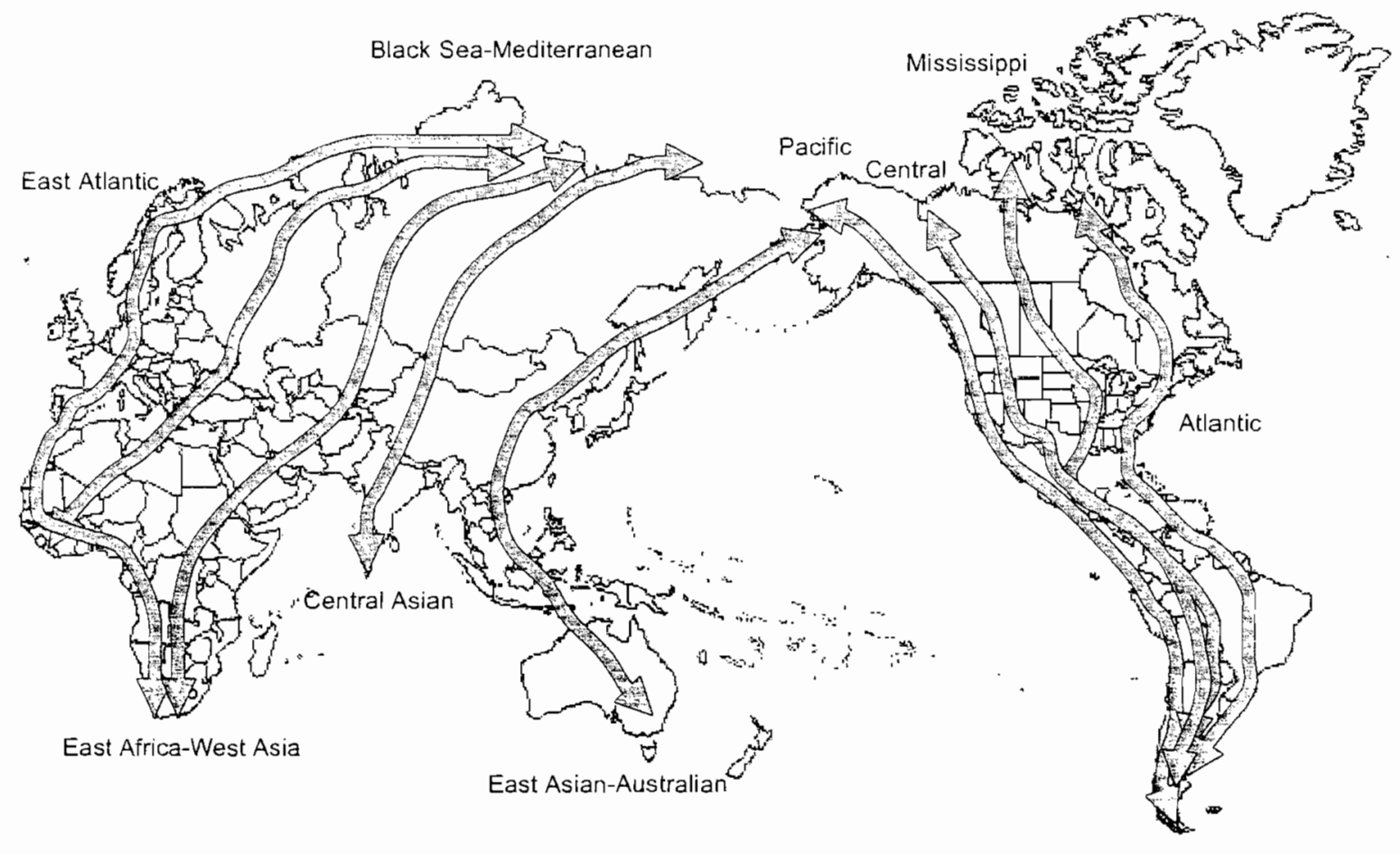

FIG. 6. Schematic representation of the nine major avian migratory flyways. 
of South America. The apparent absence of AIV may simply reflect inadequate sampling effort.

It is important to reiterate that the primary reservoir of AIV is waterfowl. Contact of waterfowl with other species, directly or through environmental contamination, will influence the dissemination of AIV. For example, waterfowl aggregate around staging and feeding areas. As a consequence, large numbers of birds are concentrated spatially and temporally, offering increased opportunity for infection by exposure to a contaminated environment. Complicating matters is the fact that, in many parts of the world, these areas are used by humans for rearing fish and poultry. There is evidence that this confluence of events has been responsible for the spillover of HPAI H5N1 from poultry operations to wild birds (e.g. Mai Po marshes, Hong Kong). Movement of infected domestic stock, or contaminated shipping containers, may further disseminate AIV and effectively create more opportunities for spillover back to wild bird populations, independently of migratory patterns. The danger of this scenario is the establishment of HPAI in wild birds, thus setting the stage for further movement of HPAI H5N1 and reinfection of domestic poultry flocks. The fact that waterfowl staging and feeding areas are used by other aquatic species (e.g. gulls [Laridae], shorebirds [Scolopacidae], herons [Ardeidae]) increases the opportunities for transmission to other potential hosts. These species may be more likely to move across flyways.

Antigenic studies indicate evidence of limited gene flow between Eurasia and North America. Concentrating on the $\mathrm{H} 2$ subtype, which caused the 1957 human influenza pandemic, several investigators conducted surveillance in migratory birds. Two $\mathrm{H} 2$ isolates derived from waterfowl migrating from Siberia to Japan (dk) Hakkaido/107/01, H2N3; dk/Hakkaido/95/01, H2N2) were shown to have antigenic similarity with North American lineages for the PB2 and PA genes, whereas the remaining gene segments were of Eurasian origin (Liu et al. 2004). Of 29 avian $\mathrm{H} 2$ isolates from North America from 1977 to 1998, most were of the North American lineage for the HA gene. However, eight, composed mostly of Charadriiformes sampled from the Delaware Bay, were identified as belonging to the Eurasian lineage (Makarova et al. 1999). This was consistent with a previous finding of a Herring Gull (Larus argentatus) viral isolate from the Delaware Bay belonging to the Eurasian lineage (Schafer et al. 1993). Similar patterns were reported in a phylogenetic analysis of the $\mathrm{M}$ genes of H13 subtypes (Widjaja et al. 2004). Interestingly, emergence and identification of the Eurasian-type isolates in North America have occurred only since 1988 and have been restricted to Charadriiformes, which suggests that a limited exchange event has given rise to a stable circulation within North America. At issue is whether increased monitoring efforts would provide better estimates of exchange events. Given the known intercontinental movement of various types of birds, this information would prove valuable in estimating the risk of a non-host-adapted AIV being introduced into and potentially colonizing a new continent.

Recent observations from China are causing some concern. Normally, waterfowl are considered the reservoir of LPAIV, and these subtypes are believed to have little effect on waterfowl. In May 2005, >6,000 wild birds, including Barheaded Geese (Anser indicus), Great Black-headed Gulls (Larus ichthyaetus), Brown-headed Gulls (L. brunnicephalus), Ruddy Shelducks (Tadorna ferruginea), and Great Cormorants (Phalacrocorax carbo) died of HPAI H5N1 at Qinghai Lake Nature Reserve in Gangcha County, Qinghai Province (Liu et al. 2005, Normile 2005). This outbreak of $\mathrm{H} 5 \mathrm{~N} 1$ is the first widescale report of this HPAIV subtype in wild birds and is significant because of its distance from the previous reported centers of outbreak. The subtype identified was antigenically related to the Peregrine Falcon (Falco peregrinus) isolate from Hong Kong. Throughout China, HPAI H5N1 has been isolated from several species of wild birds (Table 1 ), indicating widespread virulence of the " $Z$ " genotype. It might be argued that widespread dissemination of the HPAI H5N1 " $Z$ " genotype would be restricted because moribund birds would be less likely to move the virus very far. However, experimental studies have shown that the $\mathrm{H} 5 \mathrm{~N} 1$ is reverting back to nonpathogenicity in Mallards (Anas platyrhynchos) ("A" genotype), which raises the possibility that widespread transmission will occur (Hulse-Post et al. 2005). Other possible reservoirs exist as well. Kou et al. (2005) showed that a new subtype of H5N1 ("A" genotype) is circulating among Eurasian Tree Sparrows (Passer montanus) in China. Experimental infection studies showed that this subtype was highly pathogenic to chickens but 
TABLE 1. Isolation of HPAI H5.N1 from wild birds.

\begin{tabular}{|c|c|c|c|}
\hline \multirow[b]{2}{*}{ Order } & \multicolumn{3}{|c|}{ Number of species } \\
\hline & $\begin{array}{c}\text { Free- } \\
\text { ranging }\end{array}$ & Captive & Total \\
\hline Ciconiiformes & 4 & & 4 \\
\hline Phoenicopteriformes & & 1 & 1 \\
\hline Podicipediformes & 1 & & 1 \\
\hline Anseriformes & 4 & 17 & 21 \\
\hline Charadriiformes & 3 & 2 & 3 \\
\hline Falconiformes & 2 & 2 & 4 \\
\hline Strigiformes & & 4 & 4 \\
\hline Pelecaniformes & 2 & & 2 \\
\hline Passeriformes & 5 & 3 & 8 \\
\hline Columbiformes & 2 & & 2 \\
\hline
\end{tabular}

a Ellis et al. (2004a), Chen et al. (2005), International Society for Infec tious Diseases (2005), Kwon et al. (2005), Liu et al. (2005), Mase et al. (2005), Van Borm et al. (2005); Genebank entry DQ190857. not pathogenic to ducks or mice, or Eurasian Tree Sparrows. As more surveillance studies are done on wild birds, a clearer picture will emerge about the nature of the risk the $\mathrm{H} 5 \mathrm{~N} 1$ subtypes pose. Most importantly, these studies represent documentation for the occurrence of a virulent subtype of $\mathrm{H} 5 \mathrm{~N} 1$ in migratory populations of birds, raising the specter of movement of this increasingly lethal subtype across a wide geographic range.

The role of migratory birds in outbreaks of HPAI H5N1 throughout Asia and Europe is unclear. Throughout 2005, there was a progressive westward expansion of the HPAI H5N1 subtype in poultry and wild birds, with outbreaks occurring in China, Mongolia, Kazakhstan, Russia, Turkey, Ukraine, Croatia, and Romania (Fig. 7). Because many of these outbreaks were also associated with local outbreaks of H5N1 in poultry, it is not clear whether the migratory birds acquired the

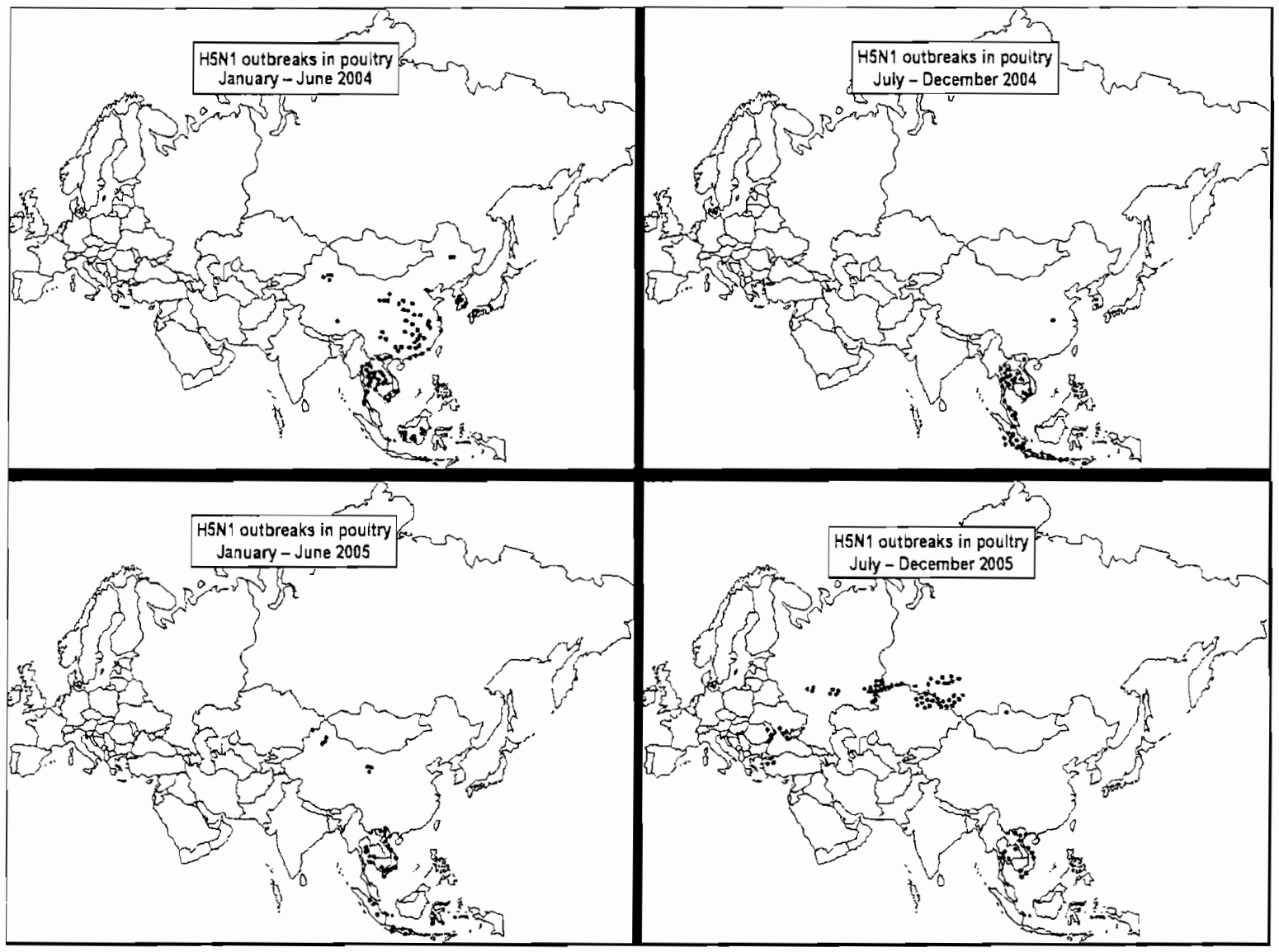

FIG. 7. Distribution of HPAI H5N1 poultry outbreaks. Larger symbols indicate numerous outbreaks over a small geographic area. Data were derived from FAO (www.fao.org/ag/AGAinfo/programmes/en/empres/ maps.html). Recent FAO reports of outbreaks in Austria, France, Iraq, Italy, Germany, Greece, and Nigeria in January 2006 indicate that wild birds moved the virus into Africa via the Black Sea-Mediterranean flyway. 
virus elsewhere and subsequently transmitted it to local poultry, or whether infection of local poultry occurred via live-bird markets, with subsequent spillover to migratory bird populations. For example, the northern and western outbreaks closely follow trans-Siberian transportation routes. Regardless, the H5N1 HPAIV subtype is affecting large numbers of birds across several flyways in Asia, which places the possible dissemination of this subtype at the boundary between Asia and Europe. The most recent records indicate that migratory birds are indeed helping to spread H5N1. At this writing, Austria, Egypt, France, Germany, Greece, Italy, and Nigeria have reported H5N1 infections in wild birds, which indicates that the Black Sea-Mediterranean flyway is a viable route of dissemination.

High-pathogenic AIV has been found in the Australian poultry industry, but the outbreaks have been limited and short-lived (Animal Health Australia 2003). Moreover, the available evidence suggests that prevalence of AIV in wild birds in Australia is low (Downie and Laver 1973; Downie et al. 1977; MacKenzie et al. 1984, 1985; Nestorowicz et al. 1987; Peroulis and O'Riley 2004). Migratory patterns of Australian birds differ from those observed in the Northern Hemisphere (Tracey et al. 2004). Ducks generally stay within the continent, with migratory patterns characterized as "nomadic." The distance and direction of movement are generally in response to ecological and climatic conditions. Despite the general isolation of this potentially important avian reservoir, there is migratory bird movement from Asia into Australia. Shorebirds and seabirds travel between Australia and the Northern Hemisphere. However, given the patterns of genetic exchange between these groups and waterfowl in North America, it may reasonably be assumed that the risk for genetic movement of AIV from shorebirds to waterfowl is low. Other birds commonly move between Asia and Australia (summarized in Tracey et al. 2004), and these birds travel through areas affected by recent outbreaks of the HPAIV H5N1 subtype. Increased efforts toward better understanding of exact migratory routes and prevalence of AIV in Austral-Asian migratory birds will lead to a better assessment of risk.

There is concern that the natural movement of birds will transport novel subtypes of AIV to new locations, thus providing opportunities for rapid evolution of new viral forms. Although there is evidence that this indeed occurs, the stability of the continental and taxonomic lineages within birds suggests that such events are uncommon. Nonetheless, the temporal and spatial dynamics of viral evolution and the risks they pose to wildlife, agriculture, and humans remain to be determined. Overlooked is the more likely possibility that human intervention, in the form of stowaways, pet trade, or smuggling, may more rapidly introduce pathogenic subtypes to new locations, as evidenced by the discovery of H5N1-infected Crested Hawk-Eagles (Spizaetus nipalensis) smuggled from Thailand to Belgium (Van Borm et al. 2005).

\section{Transmission between Species}

Evidence of transmission from wild waterfowl to poultry. - Avian influenza infection in poultry flocks may have a variety of origins (Fig. 8). Risk of transmission will be a function of prevalence of AIV in host-reservoir systems, susceptibility of poultry to circulating subtypes, number and degree of contacts between the reservoir and poultry, and the nature of biosecurity measures. For the most part, prevalence and the nature of the linkages detailed in Figure 8 are unknown. In large commercial poultry operations, many of these links are controlled. In free-range and poorly secured operations, ample opportunity for transport and transmission exists. Identifying the critical vulnerabilities is important in risk management.

At the broadest level, two lines of evidence suggest that waterfowl can be a source of AIV infection in poultry: temporal associations between AIV prevalence in wild waterfowl and poultry flock outbreaks, and genetic evidence.

In 1979 and 1980, an outbreak of H10N7 was observed on three turkey farms in Minnesota. This subtype had not previously been documented in the region, nor detected in turkeys within the United States. Antigenic analysis indicated that the AIV was indistinguishable from viruses isolated from healthy Mallards living in nearby ponds (Karunakaran et al. 1983). These coincidental observations led to a surveillance study, in which sentinel ducks were placed in ponds near turkey operations (Halvorson et al. 1985). The study also included some monitoring of wild Mallards from these ponds. Over the next several years, outbreaks of LPAIV were observed 


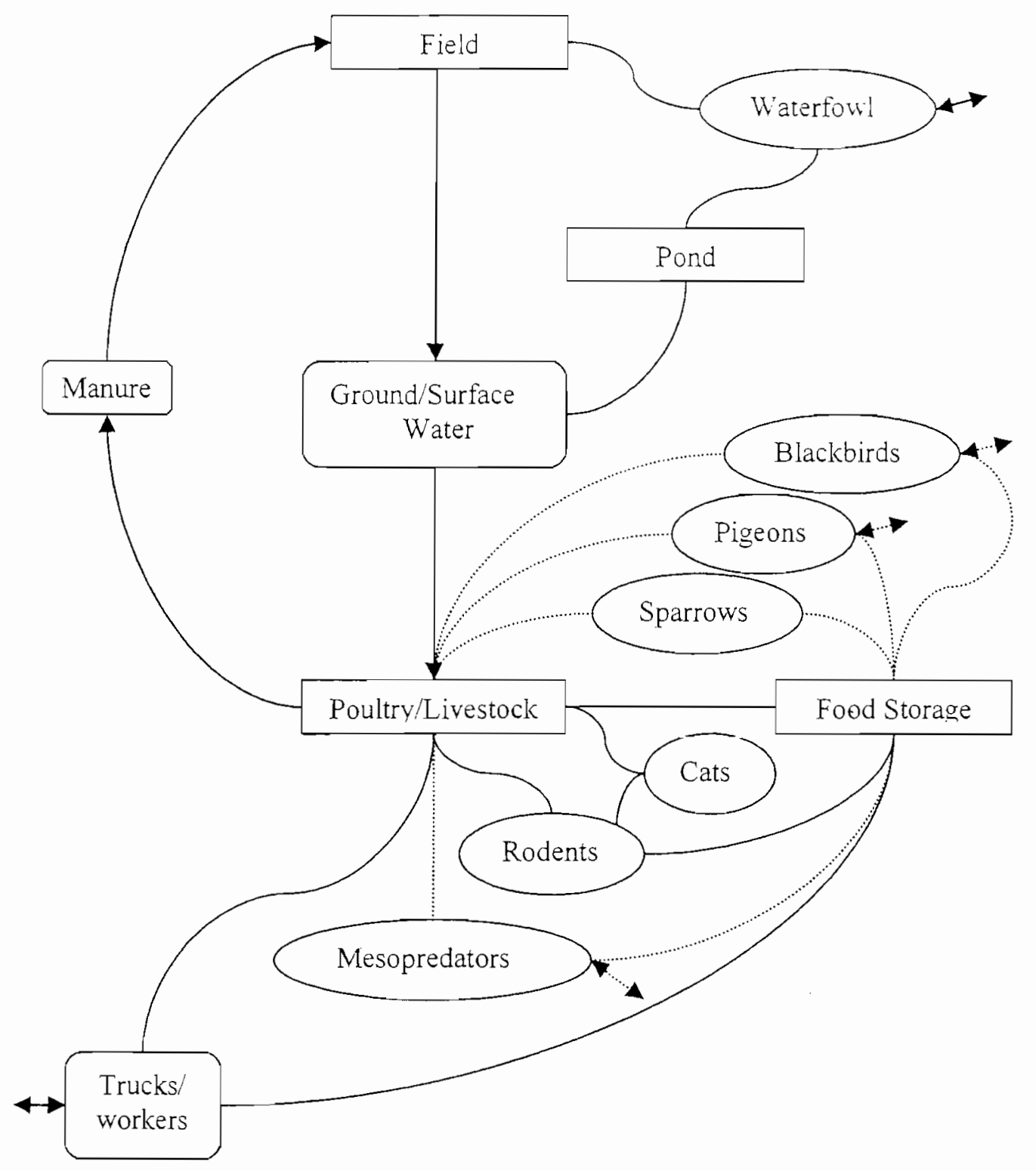

FiG. 8. Risk paths (transmission, carriage, or transport) of avian influenza virus within a farm setting. Solid lines depict higher-risk bidirectional movement. Solid lines with arrows depict migration or regional transport. Dashed lines depict unknown or lower-risk bidirectional movement. Dashed lines with arrows depict directional movement of lower risk or unknown risk.

in the turkey operations. These outbreaks were preceded by outbreaks of AIV in the sentinel ducks and wild Mallard populations (Fig. 9). Although the distribution of subtypes circulating in the Mallards differed across years (Fig. 10), there was an association between the common subtypes found in Mallards and turkeys (Halvorson et al. 1983). How the virus was transmitted from Mallards to turkeys remains unknown. That study contrasts with studies conducted during and after the 1983-1984 HPAIV outbreak in Pennsylvania, Maryland, New
Jersey, and Virginia. Nettles et al. (1985) failed to find AIV in surveys of birds and rodents within quarantined areas. The authors concluded that wildlife was not the source of AIV circulating in the poultry operations. However, given the timing of outbreaks observed in wildlife and domestic birds in the Minnesota study, it is plausible that surveillance efforts in the mid-Atlantic studies may have missed the peak of the epidemiological curve.

Nearly 200 outbreaks of LPAI (H7N1 subtype) were documented in Italy in 1999. 


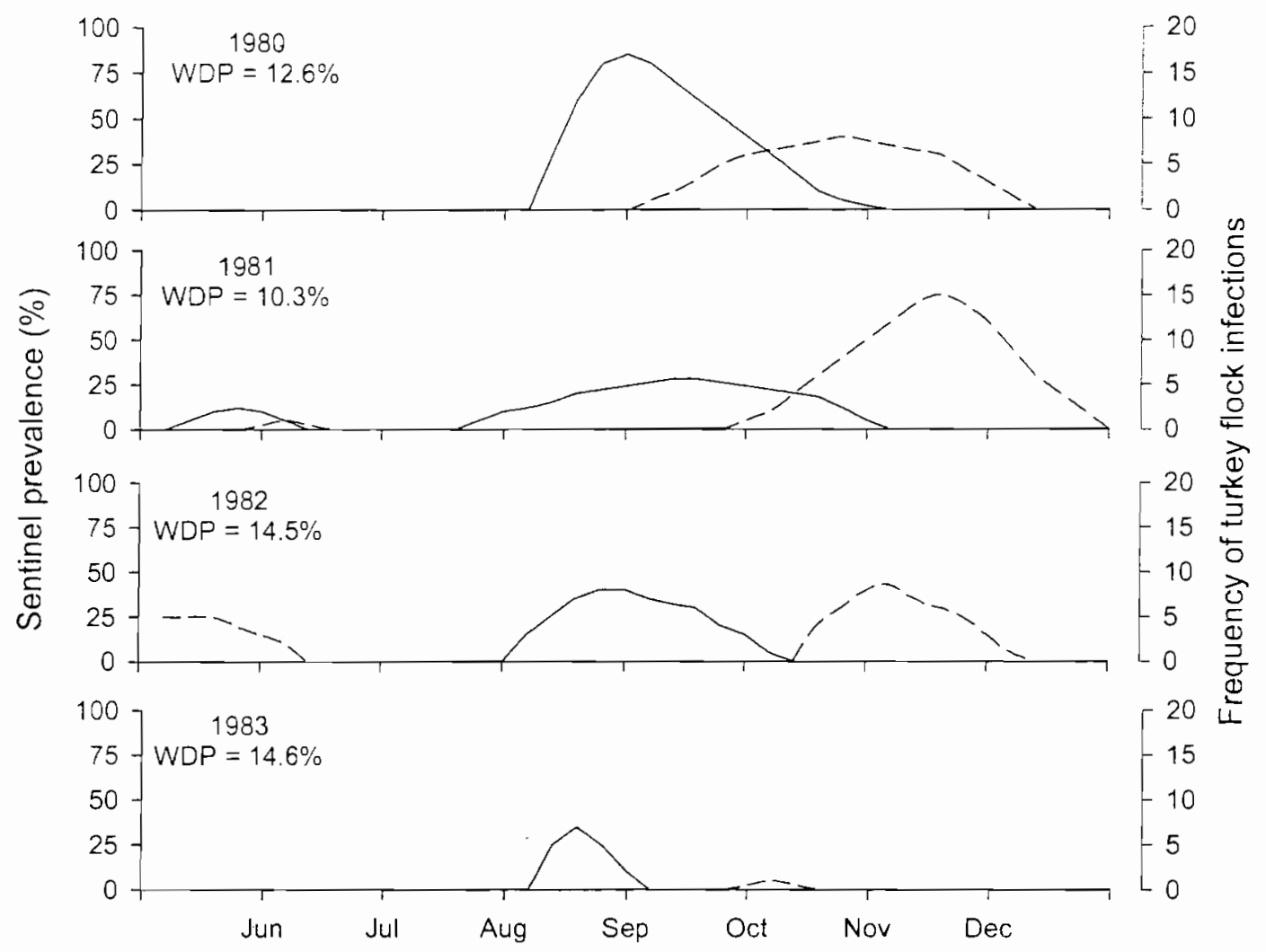

FIG. 9. Avian influenza infections in sentinel Mallards (solid lines) and domestic turkey flocks (dashed lines) for four years as a function of time of year. Results from the Department of Natural Resources survey of wild waterfowl for avian influenza are indicated in the inset (wild duck prevalence, WDP). Data adapted from Halvorson et al. (1985). Halvorson et al. (1985) placed sentinel Mallards in marshes, beginning in mid-May, over a four-year period. The sentinel Mallards were in the same environmental substrate as wild waterfowl, and physical contact between sentinels and wild waterfowl was permitted. Increased numbers of wild waterfowl were observed at the sentinel cages before detection of avian influenza virus (AIV) in sentinel Mallards. During the same period, sentinel turkeys and turkey flocks were monitored for AIV.

During the course of the outbreak, the AIV changed from a low-pathogenic form to a high-pathogenic form. The HPAIV was associated with 413 outbreaks during 2000, causing loss of $>13$ million birds, trade sanctions, and significant economic losses (Capua et al. 2002). The HPAIV (H7N1) was antigenically linked to an LPAIV subtype isolated from wild waterfowl as much as one year before the LPAIV outbreak in poultry (A/teal/Taiwan/98; Banks et al. 2000), which suggests that an LPAIV subtype was acquired by poultry from wild waterfowl and that the LPAIV changed to an HPAIV after passage in domestic poultry. A similar pattern was observed a few years later. In 2001, H7N3 was isolated from a wild duck. This isolate was compared with an H7N3 isolate subsequently derived from an outbreak in a turkey production flock in 2002-2003. There was a high degree of homology (>99\%) for PB2 and NA genes, with the exception of a 23-amino-acid deletion in the NA stalk (Campitelli et al. 2004).

The deletion in the NA stalk is characteristic of adaptation of LPAIV found in wild waterfowl to HPAIV forms found in poultry (Castrucci and Kawaoka 1993). A second virulence attribute centers around the HA cleavability (Horimoto and Kawaoka 1994). Introductions of mutations by error-prone RNA polymerase, followed by selection after passage in the adapting host, can result in conversion of LPAIV to HPAIV. Ito et al. (2001) identified the amino acid sequence changes from the LPAI (RETR) to HPAI (RRKKR) at the HA cleavage site as critical to development of HPAI in chickens. These and other studies (Matrosovich et al. 1999) suggest that changes in both HA and NA may be required for the adaptation of AIV from wild birds to chickens, and that 


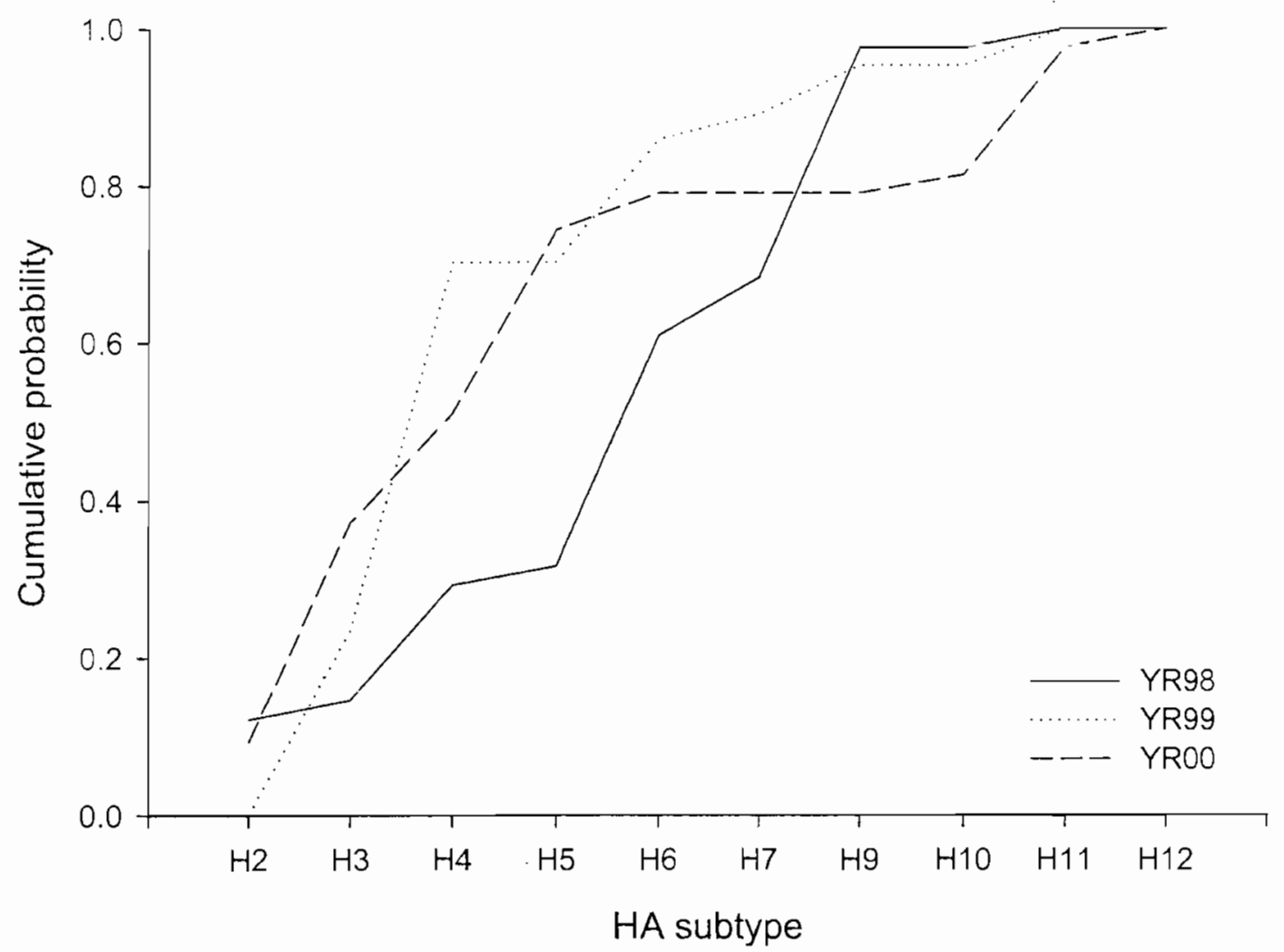

FIG. 10. Cumulative probability distribution of HA subtypes for Minnesota waterfowl over three years. Distribution of subtypes circulating among waterfowl HA subtype differed among years. Data adapted from Hanson et al. (2003).

chickens may also be an important intermediate host in zoonotic transmission.

Most AIV circulating in wild waterfowl is considered to be LPAIV, producing no observable disease in their host populations. Even in nonadapted hosts (e.g. chickens), most subtypes derived from wild waterfowl are low-virulence (Otsuki et al. 1988). Yet the studies by Ito et al. (2001), Campitelli et al. (2004), and others suggest that surveillance for LPAIV in wild waterfowl is an appropriate activity for assessing risk, given the possibility for antigenic shift to HPAIV after passage in poultry.

Shifts in virulence are not unidimensional. Multiple subtypes of H3N2 human-influenza subtypes were isolated from diseased chickens in Italy. Antigenic analysis showed that the source was not likely in nearby infected pig operations, but rather in Eurasian birds. This illustrates that chickens and turkeys can circulate multiple subtypes from multiple sources and that these subtypes were circulating in the wild bird population one year before outbreaks at poultry facilities (Campitelli et al.
2002, 2004). Recent characterizations of AIV in Hong Kong further illustrate that transmission can go from domestic poultry back to wildlife, with an accompanying shift in virulence. For example, $\mathrm{H} 5 \mathrm{~N} 1$ isolates derived in Hong Kong from outbreaks in 1997 and 2001-2003 exhibited typical high mortality in domestic gallinaceous birds and no apparent effect on domestic waterfowl and other wild birds during 1997 and 2001. However, beginning in 2002, mortality was reported (Ellis et al. 2004a) in waterfowl (i.e. Domestic Goose [Anser anser domesticus], Canada Goose [Branta canadensis], Black Swan [Cygnus atratus], Black-necked Swan [C. melanocoryphus], Wood Duck [Aix sponsa], Brazilian Duck [Amonzonetta brasiliensis], White-cheeked Pintail [Anas bahamensis], Chestnut Teal [A. castanea], Red Shoveler [A. platalea], Chiloe Wigeon [A. sibilatrix], Silver Teal [A. versicolor], and Bar-headed Goose [A. indicus]) and then in other wild birds (Little Egret [Egretta garzetta], Gray Heron [Ardea cinerea], Greater Flamingo [Phoenicopterus ruber], Black-headed Gull [Larus ridibundus], Rock Pigeon [Columba livia], and 
Eurasian Tree Sparrow [Passer montanus]), which suggests that antigenic shifts occurred for increased virulence across multiple hosts. It also appears that domestic ducks played an important role in the generation and maintenance of the new virus and that wild birds were important to its subsequent spread across Asia (Li et al. 2004), which suggests, for the first time, that the movement of virus is not always in the direction from wildlife to domesticated birds. This observation has implications not only for the maintenance and dissemination of virulent subtypes of virus, but also for the health of wild bird populations, as indicated by recent wild bird mortalities associated with $\mathrm{H} 5 \mathrm{~N} 1$ subtypes in northwestern China (Liu et al. 2005, Normile 2005).

Evidence of transmission from non-waterfowl birds to poultry. - It is generally assumed that the subtypes circulating in wild birds are of low consequence to survivorship in their natural hosts. However, no studies have prospectively and formally addressed this. Nor is it well known to what degree circulating virus among non-waterfowl wild birds is of agricultural or zoonotic concern. There are isolated reports implicating European Starlings (Sturnus oulgaris) and sparrows (Passer domesticus and $P$. montanus) in outbreaks of avian influenza in poultry (Nestorowicz et al. 1987). The Rock Pigeon (Columba livia) is another peridomestic species that lives in proximity to humans and agricultural operations, making its presence a risk factor for transmission of AIV. Surprisingly, little is known about the Rock Pigeon's role as carriers for this virus. Overall, however, it is doubtful that Rock Pigeons are an important or viable reservoir for AIV. Several investigators have sampled feral and racing Rock Pigeons and failed to find any evidence of infection (Kaleta and Honicke 2004). Rock Pigeons experimentally infected with HPAI (CK/PA H5N2, CK/Australia $\mathrm{H} 7 \mathrm{~N} 7, \mathrm{~A} / \mathrm{CK} / \mathrm{HK} / 220 / 97 \mathrm{H} 5 \mathrm{~N} 1$ ) and LPAI (CK/ PA H5N2, emu/TX H7N1) remained healthy and did not shed virus up to 21 days postinfection (Panigrahy et al. 1996, Perkins et al. 2002). However H5N1 subtypes recently circulating in Asia indicate a shift in pathogenesis. An H5N1 isolate was detected in a dead feral Rock Pigeon during the 2001 Hong Kong outbreak (Ellis et al. 2004a), which suggests that this emergent subtype is a pathogen to at least some wild birds. Liu et al. (2003) reported low prevalence $(0.5 \%)$ for Rock Pigeons surveyed in Chinese live-bird markets. Recent events aside, in the absence of evidence for disease or shedding, the only remaining route for transmission is mechanical carriage. Thus, the importance of Rock Pigeons as disseminators of virus may be limited to redistribution by mechanical means during an active outbreak.

Transmission between wild birds and other wildlife. - Little monitoring has been done to determine the degree to which mammalian wildlife are exposed to AIV, what effects this might have on their health, and how infection affects the virus (i.e. generation of reassortants). The avian H10N4 and H10N7 subtypes were isolated from mink in Sweden. Antigenic analysis showed a high degree of homology (98\%) between mink (Mustela vison) and contemporary isolates from fowl and a Mallard, which suggests a direct invasion of the mink population by an avian viral subtype (Berg et al. 1990, Englund 2000). An example of adaptation of an avian subtype to mammals was reported by Hinshaw et al. (1984). The avian subtype H4N5 was isolated from dying harbor seals (Phoca vitulina). Antigenic analysis suggested that the virus was similar to recent avian subtypes. Unlike previous subtypes isolated from mammals, this subtype could replicate in the intestinal tracts of ducks, a characteristic of avian subtypes. We have observed antibody to $\mathrm{H} 6 \mathrm{~N} 4$ in a raccoon (Procyon lotor) near farm sites reporting poultry infection by the same subtype. The significance of this observation is twofold. First, the raccoon was located near a farm without reported AIV activity, which indicates movement of potential carriers across the operational landscape. Second, avian subtypes adapting to other mammals may increase risks for human and livestock disease.

\section{Human Risks}

Human risks. - Until recently, the only influenza circulating in human populations consisted of $\mathrm{H} 1$ and $\mathrm{H} 3$ subtypes. The H2N2 subtype responsible for the 1957 pandemic has not been found since 1968; thus, several generations of humans have no immunity to this virus. All HA and NA subtypes are found in waterfowl and wild bird reservoirs and have the potential to provide new virulent combinations to the human influenza arsenal, as was the case in the 1957 and 1968 pandemics (Kawaoka et al. 1989). This is also the case 
with the 1997 outbreak of AI in Hong Kong. This highly virulent $\mathrm{H} 5 \mathrm{~N} 1$ subtype had acquired the new ability to be transmitted directly from birds to humans, with deadly results (6 of 18 infected people died). Even more disturbing is that the H5N1 isolates from 1999 through 2002 were becoming increasingly pathogenic for mammals (Chen et al. 2004) and that H5N1 is increasing its geographic range. Fortunately, this subtype has not become efficient at transmission from human to human (reviewed in Lipatov et al. 2004). If it acquires this ability, a global pandemic is a distinct possibility.

In 2003, an HPAIV subtype (H7N7) infected poultry flocks in The Netherlands. Control measures resulted in workers becoming infected and contracting viral conjunctivitis. The virus replicated and was able to spread from human to human, and there was one fatality (Fouchier et al. 2004). Quick intervention by multinational authorities, including the OIE, prevented the spread of this subtype and resulted in its eradication.

Another avian-adapted subtype that has developed the capacity to infect humans is H9N2 in Asia (Lin et al. 2000). Although this subtype differed in its surface HA and NA components, its six internal genes were similar to the $1997 \mathrm{H} 5 \mathrm{~N} 1$ avian isolates. This subtype is now endemic in Eurasia and is clearly of avian origin, yet it has adapted to preferentially bind to the human sialic acid receptor. Two cases of human infection occurred in 1999 in Hong Kong, causing mild disease, and the virus has also been found in pigs (Peiris et al. 1999, 2001).

Southeast Asia, particularly Hong Kong, seems to be a hotbed for the generation of new subtypes of AIV. Livestock husbandry practices that include housing domestic birds in proximity to pigs and humans and the use of live-bird markets creates a scenario ripe for the recombination of AIV subtypes creating potential human pathogens. The reservoir of genetic diversity present in wild birds worldwide only compounds the problem of prevention and control of AI. As with pigs, the increased rate of novel subtypes and subtypes of human influenza arising since the mid-1990s is a concern and poses an increased risk to human populations. Whether the next pandemic comes out of Asia or elsewhere, the only certainty is that it will happen.

\section{BIOSECURITY}

Control of AI outbreaks in poultry typically involves culling of infected flocks, quarantine, and implementation of strict biosecurity measures, including prevention of spread by human workers involved in control. The role that wild animals have in transmission or environmental contamination of farm sites is largely unknown. It is assumed that transmission is an uncommon event, as evidenced by the relatively few outbreaks. However, despite the low frequency of transmission, genetic evidence indicates that wildlife, and probably waterfowl in particular, are the source of the AIV in many poultry outbreaks. How and when these contacts occur, and whether they are direct or indirect, is simply not known (Fig. 11). Better monitoring would prove useful in assessing the level and nature of risk and deciding what precautions need to be implemented. In the absence of specifically identified risk paths, general biosecurity measures should be observed (i.e. minimizing wildlife contact with farm stock and their resources, including food and water). Even indirect links may represent a level of risk. For example, workers engaged in activities in and around farm sites may inadvertently expose themselves to environmental contamination. Thus, a biosecurity program that includes disinfection prior to entry should be enforced. In the event of a breach of biosecurity, containment becomes the operative mode.

In recent years, vaccination of flocks against AIV during outbreaks has provided health officials and growers with a new weapon in their arsenal for prevention and control of AI (Ellis et al. 2004b). In Mexico, extensive use of inactivated AIV vaccines as well as recombinant fowlpox avian influenza (H5) vaccines, helped to curtail the 1994 outbreak of HPAIV. More than one billion doses were administered from 1995 to 2001, and no cases of HPAIV have been documented since (Villarreal-Chavez and Rivera-Cruz 2003). Vaccination was also employed to contain the outbreaks in Italy and The Netherlands (Capua and Marangon 2003). Currently in Asia, vaccination is being used in varying degrees to control the H5N1 strain. Hong Kong now has made vaccination of flocks mandatory, and China uses vaccines in areas where the virus has been found; however, Thailand does not allow use of vaccines (Normile 2005). 


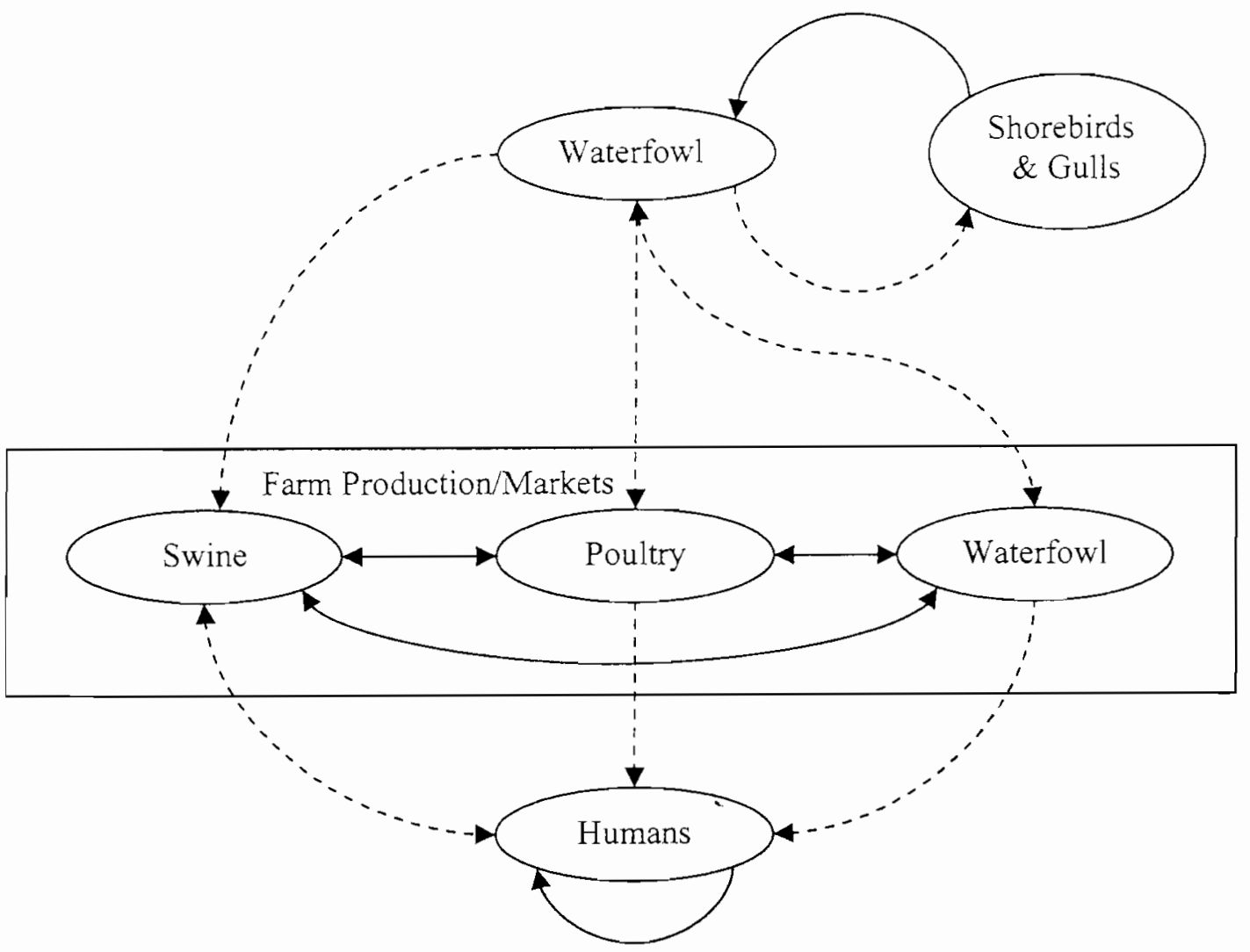

FIG. 11. Risk paths for transmission of avian influenza from wild bird populations to agriculture and humans. Arrows indicate the most common direction of reassortment flow or transmission.

Use of vaccines is not without controversy. Vaccinating poultry can make monitoring and surveillance difficult, and using a single vaccine strain of AIV may drive the evolution of AIV into new genetic variants (Suarez et al. 2004). These issues aside, it seems that use of $\mathrm{AI}$ vaccines will continue and can help reduce the spread of the disease. The future of $\mathrm{AI}$ vaccines may reside in the new technologies of molecular biology and recombinant techniques to make rapid and efficacious vaccines for specific subtypes and threats (Hoffmann et al. 2002, Webby et al. 2004).

\section{SuMMARY}

Influenza A viruses are naturally reservoired in wild bird populations and generally exist as low-pathogenic subtypes. Historically, concern about AIV in wild birds is related to its potential effects on agriculture and human health, and not on the health of wild bird populations. Several subtypes (primarily $\mathrm{H} 5$ and $\mathrm{H} 7$ ) have caused severe outbreaks of disease in domestic bird populations. Genetic and spatial temporal analyses suggest that, in many cases, the origin of these high-pathogenic subtypes may be wild bird populations that transmit low-pathogenic forms to domestic birds; after passage in domestic birds, the low-pathogenic subtypes convert to high-pathogenic subtypes. These observations suggest that monitoring AIV activity in wild bird populations, especially waterfowl, may improve risk assessment for poultry producers. The risk paths (i.e. how the virus gets from waterfowl to domestic birds) are not well understood and should be the subject of further research. The number of outbreaks of high-pathogenic AIV is increasing, as are the number of domestic birds that are culled in efforts to contain the spread of infection. These efforts have enormous economic implications. More recently, there is evidence from Asia that high-pathogenic AIV is being transmitted from domestic birds back to wild birds. Large die-offs have been observed. This trend has two implications. First, movement of virulent forms of AIV are increasing because of the migratory patterns of wild birds. This will make containment more difficult and hinder 
the global effort to control high-pathogenic AIV. Second, because these subtypes are pathogenic to wild birds, their populations may be negatively affected, especially in species that are threatened or endangered.

During the past century, all influenza pandemics, except the 1918 pandemic, arose from the Eurasian lineage of AIV. Subtypes implicated in human disease include $\mathrm{HA}(\mathrm{H} 1, \mathrm{H} 2$, H3) and NA (N1, N2). The 1918 pandemic arose from the North American lineage. However, more recently human disease has been caused by additional $\mathrm{HA}$ subtypes $\mathrm{H} 5, \mathrm{H} 7$, and $\mathrm{H} 9$. Moreover, the host range of $\mathrm{H} 5 \mathrm{~N} 1$ has expanded to other mammals, including domestic cats, leopards, tigers, pigs, pilot whales (Globicephala melaena), and seals. Adaptation to mammalian hosts poses human health and conservation problems.

Co-infection of a host with avian and human flu subtypes is believed to provide opportunities for reassortment and potential generation of subtypes with pandemic potential. Both pigs and quail are hosts of concern. Although surveillance has focused on domestic production of these species, the role of the natural disease ecology of feral swine and quail in relation to the generation of avian and human reassortants is an area of concern that has not been investigated. Direct transmission from birds to humans or other mammals is also possible, as evidenced by human infections caused by H9N2. Because the H5N1 subtype has become endemic to Southeast Asia and the human population is immunologically naïve, concern about a possible pandemic is increasing.

Although there is little anyone can do about the natural reservoir of AIV in birds, increased information about how the viruses are maintained, transmitted, and moved across the landscape in nature will provide valuable information about agricultural and human health risk-assessment.

\section{Literature Cited}

Alexander, D. J. 2000. A review of avian influenza in different bird species. Veterinary Microbiology 74:3-13.

Alexander, D. J.2001. Ecology of avian influenza in domestic birds. Pages 25-34 in Emergence and Control of Zoonotic Ortho- and Paramyxovirus Diseases: Symposium Proceedings (B. Dodet and M. Vicari, Eds.). John Libbey Eurotext, Montrolige, France.

Alfoxiso, C. P., B. S. Cowen, and H. van Campex. 1995. Influenza A viruses isolated from waterfowl in two wildlife management areas of Pennsylvania. Journal of Wildlife Diseases 31: 179-185.

Amin, A., M. A. Shalaby, And I. Z. Imam. 1980. Studies on influenza virus isolated from migrating birds in Egypt. Comparative Immunology, Microbiology and Infectious Diseases 3:241-246.

Animal Health Australia. 2003. Disease Strategy: Highly Pathogenic Avian Influenza. Australian Veterinary Plan (AUSVETPLAN), version 3. Animal Health, Canberra, Australia.

BaIGENT, S. J., AND J. W. MCCAULEy. 2003. Influenza type $A$ in humans, mammals and birds: Determinants of virus virulence, host-range and interspecies transmission. Bioessays 25:657-671.

Banks, J., E. C. Speidel, J. W. McCauley, and D. J. AleXANDer. 2000. Phylogenetic analysis of $\mathrm{H} 7$ haemaglutinin subtype influenza A viruses. Archives of Virology 145:1047-1058.

BECKER, W. B. 1966. Isolation and classification of tern virus: Influenza virus $\mathrm{A} /$ tern/South Africa/1961. Journal of Hygiene 64:309-320.

Berg, M., L. Englund, I. A. Abusugra, B. Klingeborn, and T. Linné. 1990. Close relationship between mink influenza (H10N4) and concomitantly circulating avian influenza viruses. Archives of Virology 113:61-71.

Bounreaul, A., J. Lecomte, and V. S. Hinshaw. 1980. Caracterisation antigenique des virus influenza $A$ isoles des oiseaux captures dans l'Ontario, le Quebec et les provinces maritimes durant la saison 1977. Revue Canadienne de Biologie 39:107-114.

Campitelli, L., C. Fabiani, S. Puzelli, A. Fioretti, E. Foni, A. De Marco, S. Krauss, R. G. Webster, and I. Donatelli. 2002. H3N2 influenza viruses from domestic chickens in Italy: An increasing role for chickens in the ecology of influenza? Journal of General Virology 83: $413-420$.

Campitelli, L., E. Mogavero, M. A. De Marco, M. Delogu, S. Puzelli, F. Frezza, M. Facchini, C. Chiapponi, E. Foni, P. Cordioli, and others. 2004. Interspecies transmission of an H7N3 influenza virus from wild birds to intensively reared domestic poultry in Italy. Virology 323:24-36.

Capua, I., and D. J. Alexander. 2004. Avian influenza: Recent developments. Avian Pathology 33:393-404.

Capua, I., and S. Marangon. 2003. Vaccination policy applied for the control of avian influenza in Italy. Developmental Biology (Basel) 114:213-219. 
Capla, I, F. Mutinelin, M. D. Pozza, I. Doxatelli, 5. Plzelli, And F. M. Cancellotti. 2002. The 1999-2000 avian influenza (H7N1) epidemic in Italy: Veterinary and human health implications. Acta Tropica 83:7-11.

Castrlcci, M. R., I. Doñateli, L. Sidoli, G. BarigazZI, Y. KaWAOKA, AND R. G. Webster. 1993. Genetic reassortment between avian and human influenza $A$ viruses in Italian pigs. Virology 193:503-506.

Castrucci, M. R., and Y. Kawaoka. 1993. Biologic importance of neuraminidase stalk length in influenza A virus. Journal of Virology 67: 759-764.

Chambers, T. M., V. S. Hinshaw, Y. Kawaoka, B. C. Easterday, and R. G. Webster. 1991. Influenza viral infection of swine in the United States 1988-1989. Archives of Virology 116:261-265.

Chen, H., G. Deng, Z. Li, G. Tian, Y. Li, P. Jiao, L. Zhang, Z. LiU, R. G. Webster, and K. Yu. 2004. The evolution of H5N1 influenza viruses in ducks in southern China. Proceedings of the National Academy of Sciences USA 101: 10452-10457.

Chen, H., G. J. D. Smith, S. Y. ZhanG, K. Qin, J. Wang, K. S. Li, R. G. Webster, J. S. M. Peiris, And Y. Guan. 2005. Avian flu: H5N1 virus outbreak in migratory waterfowl. Nature 436: 191-192.

Choi, Y. K., J. H. Lee, G. Erickson, S. M. Goyal, H. S. Joo, R. G. Webster, and R. J. Webby. 2004. $\mathrm{H} 3 \mathrm{~N} 2$ influenza virus transmission from swine to turkeys, United States. Emerging Infectious Diseases 10:2156-2160.

Clark, L. 2003. A review of pathogens of agricultural and human health interest found in Canada Geese. Pages 326-334 in Proceedings of the 10th Wildlife Damage Management Conference (K. A. Fagerstone and G. W. Witmer, Eds.). The Wildlife Society, Fort Collins, Colorado.

Davison, S., D. Galligan, T. E. Eckert, A. F Ziegler, and R. J. Eckroade. 1999. Economic analysis of an outbreak of avian influenza, 1997-1998. Journal of the American Veterinary Medical Association 214:1164-1169.

de Boer, G. F., C. van Maanen, J. T. Siebinga, AND W. BACK. 1992. Classic towl plague (avian influenza) and milder influenza infections in birds and mammals. Tijdschrift voor Diergeneeskunde 117:735-740.

Domingo, E., C. Escarmis, N. Sevillla, A. Moya, S. F. Elena, J. Quer, I. S. Novella, and J. J. Holland. 1996. Basic concepts in RNA virus evolution. FASEB Journal 10:859-863.

Domingo, E., And J. J. Holland. 1994. Mutation rates and rapid evolution of $\mathrm{R} N A$ viruses. Pages 161-184 in The Evolutionary Biology of
Viruses (S. S. Morse, Ed.). Raven Press, New York.

DoNis, R. O., W. J. BeAx, Y. KAWAOKt, AND R. G Webster. 1989. Distinct lineages of influenza virus $\mathrm{H} 4$ hemagglutinin genes in different regions of the world. Virology 169:408-117.

Downie, J. C., V. S. Hinshaw, and W. G. Laver. 1977. The ecology of influenza. Isolation of type $A$ influenza viruses from Australian pelagic birds. Australian Journal of Experimental Biology and Medical Science 55:635-643.

Downie, J. C., and W. G. Laver. 1973. Isolation of type A influenza virus from an Australian pelagic bird. Virology 51:259-269.

DraKe, J. W. 1993. Rates of spontaneous mutation among RNA viruses. Proceedings of the National Academy of Sciences USA 90: $4171-4175$.

Elis, T. M., R. B. Bousfield, L. A. Bissett, K. C. Dyrting, G. S. Luk, S. T. Tsim, K. SturmRamirez, R. G. Webster, Y. Guan, and J. S. Malik Peiris. 2004a. Investigation of outbreaks of highly pathogenic H5N1 avian influenza in waterfowl and wild birds in Hong Kong in late 2002. Avian Pathology 33:492-505.

Ellis, T. M., C. Y. H. C. LeUng, M. K. W. Chow, L. A. Bisset, W. Wong, Y. Guan, and J. S. M. Peiris. 2004b. Vaccination of chickens against H5N1 avian influenza in the face of an outbreak interrupts virus transmission. Avian Pathology 33:405-412.

ENGLUND, L. 2000. Studies on influenza viruses H10N4 and H10N7 of avian origin in mink. Veterinary Microbiology 74:101-107.

Fanning, T. G., R. D. Slemons, A. H. Reid, T. A. JAnCzewski, J. Dean, and J. K. Taubenberger. 2002. 1917 avian influenza virus sequences suggest that the 1918 pandemic virus did not acquire its hemagglutinin directly from birds. Journal of Virology 76:7860-7862.

FAO. 2004a. Update on the avian influenza situation. Food and Agriculture Organization of the United Nations. FAOAIDEnews 26:1-12.

FAO. 2004b. Animal Health Special Reports. Avian Influenza-Related Issues. [Online.] Available at www.fao.org/ag/againfo/subjects/en/health/ diseases-cards/avian_issues.html.

Frelds, B. N., D. M. Knipe, and P. M. Howley, EDs. 1996. Fields Virology, 3rd ed. LippincottRaven, Philadelphia.

Fouchier, R. A. M., T. Kuiken, G. RimmelzwaAn, and A. Osterhaus. 2005. Global task force for influenza. Nature 435:419-420.

Fouchier, R. A. M., P. M. Schneeberger, F. W. Rozendaal, J. M. Broekman, S. A. Kemink, V. Munster, T. Kuiken, G. F. RimmelzwaAn, M. Schutten, G. J. VAN Doornum, and others. 2004. Aviar influenza A virus 
(H7N7) associated with human conjunctivitis and a fatal case of acute respiratory distress syndrome. Proceedings of the National Academy of Sciences USA 101:1356-1361.

Garcia, M., D. L. Slakez, J. M. Crawford, J. W. Latrmer, R. D. Siemois, D. E. Swayne, avd M. L. Perdue. 1997. Evolution of H5 subtype avian influenza $A$ viruses in North America. Virus Research 51:115-124.

Gibbs, M. J., J. S. Armstrong, axd A. J. Gibbs. 2001. The haemagglutinin gene, but not the neuraminidase gene, of 'Spanish flu' was a recombinant. Philosophical Transactions of the Royal Society of London, Series B 356:1845-1855.

Gipson, P. S., J. K. Veatch, R. S. Matlack, and D. P. JONES. 1999. Health status of a recently discovered population of feral swine in Kansas. Journal of Wildlife Diseases 35:624-627.

Hahn, J., AND F. D. Clark. 2002. A short history of the cleanup costs associated with major disease outbreaks in the United States. Avian Advice 4:12-13.

HALL, C. 2004. Impact of avian influenza on U.S. poultry trade relations-2002: $\mathrm{H} 5$ or $\mathrm{H} 7$ low pathogenic avian influenza. Annals of the New York Academy of Sciences 1026:47-53.

Halvorson, D., D. Karunakaran, D. Senne, C. Kelleher, C. Bailey, A. Abraham, V. Hinshaw, AND J. Newman. 1983. Epizootiology of avian influenza-Simultaneous monitoring of sentinel ducks and turkeys in Minnesota. Avian Diseases 27:77-85.

Halvorson, D. A., C. J. Kelleher, and D. A. Senne. 1985. Epizootiology of avian influenza: Effect of season on incidence in sentinel ducks and domestic turkeys in Minnesota. Applied and Environmental Microbiology 49:914-919.

Hanson, B. A., D. E. Stallknecht, D. E. Swayne, L. A. Lewis, and D. A. Señne. 2003. Avian influenza viruses in Minnesota ducks during 1998-2000. Avian Diseases 47:867-871.

Hinshaw, V. S., W. J. Bean, R. G. Webster, J. E. ReHG, P. Fiorelli, G. Early, I. R. Geraci, and D. J. St. Aubin. 1984. Are seals frequently infected with avian influenza viruses? Journal of Virology 51:863-865.

Hinshaw, V. S., and R. G. Webster. 1982. The natural history of influenza A viruses. Pages 79-104 in Basic and Applied Influenza Research (A. S. Beare, Ed.). CRC Press, Boca Raton, Florida.

Hinshaw, V. S., R. G. Webster, B. C. Easterday, AND W. J. BeAN, JR. 1981. Replication of avian influenza $A$ viruses in mammals. Infection and Immunity 34:354-361.

Hinshaw, V. S., R. G. Webster, and B. Turner. 1978. Novel influenza A viruses isolated from Canadian feral ducks: Including strains antigenically related to swine influenza (Hsw1N1) viruses. Journal of General Virology 41: $115-127$.

Hinshai, V. S., J. M. Wood, R. G. Webster, R. Deibel, AND B. Tliner. 1985. Circulation of influenza viruses and paramyxoviruses in waterfowl originating from two different areas of North America. Bulletin of the World Health Organization 63:711-719.

Hofmani, E., S. Kralss, D. Perez, R. Webby, AND R. G. Webster. 2002. Eight-plasmid system for rapid generation of influenza virus vaccines. Vaccine 20:3165-3170.

Hormoto, 'T., AND Y. KaWAOKA. 1994. Reverse genetics provides direct evidence for a correlation of hemagglutinin cleavability and virulence of an avian influenza A virus. Journal of Virology 68:3120-3128

Hulse-Post, D. J., K. M. Sturu-Ramirez, J. Humberd, P. Seller, E. A. Govorkova, S. Krauss, C. Scholtissek, P. Puthavathana, C. Buranathai, T. D. Nguyen, and others. 2005. Role of domestic ducks in the propagation and biological evolution of highly pathogenic H5N1 influenza viruses in Asia. Proceedings of the National Academy of Sciences USA 102: 10682-10687.

Iftimovici, R., V. Iacobescu, A. L. Peterescu, A. Mitiu, and M. Chelaru, 1980. Isolation of influenza virus A/LSSR/90/77 (H1N1) from wild birds. Revue Roumaine de Medecine: Virologie 31:243.

International Society for Infectious Diseases. 2005. Avian influenza, Eurasia (22): H5N1. ProMED-mail, 21 October: 20051021.3075. [Online.] Available at www.promedmail.org.

Isachenko, V. A., L. Y. Zakstelskaya, I. G. Roslaya, L. D. Odinok, E. V. Molibog, and D. Lvov. 1974. Strains similar to Hong Kong variant of influenza virus isolated from synanthropic and wild migrating birds (in Russian). lvanovsky Institute of Virology 2:156-165.

Ito, T., J. N. Couceiro, S. Kelm, L. G. Baum, S. Krauss, M. R. Castrucci, I. Donatelli, H. Kida, J. C. Paulson, R. G. Webster, and Y. KawaOKA. 1998. Molecular basis for the generation in pigs of influenza $A$ viruses with pandemic potential. Journal of Virology 72 : 7367-7373.

Ito, T., H. Goto, E. Yamamoto, H. Tanaka, M. Takeuchi, M. Kuwayama, Y. Kawaoka, and K. Otsuki. 2001. Generation of a highly pathogenic avian influenza $A$ virus from an avirulent field isolate by passaging in chickens. Journal of Virology 75:4439-4443.

Ito, T., K. Okazaki, Y. Kawaoka, A. Takada, R. G. Webster, And H. K1DA. 1995. Perpetuation of influenza $A$ viruses in Alaskan waterfowl reservoirs. Archives of Virology 140:1163-1172. 
Kaleta, E. F., AND A. Hoxicke. 2004. Review of the literature on avian influenza $A$ viruses in pigeons and experimental studies on the susceptibility of domestic pigeons to influenza A viruses of the haemagglutinin subtype $\mathrm{H} 7$. Deutsche Tierarztliche Wonchenschrift 111: $467-472$.

Karasin, A. I., I. H. Brown, S. Carman, and C. W. Olsen. 2000. Isolation and characterization of $\mathrm{H} 4 \mathrm{~N} 6$ avian influenza viruses from pigs with pneumonia in Canada. Journal of Virology 74 : 9322-9327.

Karunakaran, D., V. Hinshaw, P. Poss, J. Newman, AND D. Halvorson. 1983. Influenza A outbreaks in Minnesota turkeys due to subtype H10N7 and possible transmission by waterfowl. Avian Diseases 27:357-366.

Kawoaka, Y., T. M. Chambers, W. L. Sladen, and R. G. Webster. 1988. Is the gene pool of influenza viruses in shorebirds and gulls different from that in wild ducks? Virology 163:247-250.

Kawaoka, Y., S. Krauss, and R. G. Webster. 1989. Avian-to-human transmission of the PB1 gene of influenza A viruses in the 1957 and 1968 pandemics. Journal of Virology 63:4603-4608.

Keawcharoen, J., K. Oraveerakul, T. Hilken, R. Fouchier, A. Amonsin, and S. Payungrorn, S. Noppornpanth, S. Wattanodorn, A. Theamboonlers, R. Tantilertcharoen, and others. 2004. Avian influenza H5N1 in tigers and leopards. Emerging Infectious Diseases 10:2189-2191.

Khatchikian, D., M. Orlich, and R. Rott. 1989. Increased viral pathogenicity after insertion of a 285 ribosomal-RNA sequence into the hemagglutinin gene of an influenza virus. Nature 340:156-157.

KidA, H. 1997. Ecology of influenza viruses in animals and the mechanism of emergence of new pandemic strains. Nippon Rinsho 10: 2521-2526.

Kida, H., T. Ito, J. Yasuda, Y. Shimizu, C. Itakura, K. F. Shortridge, Y. Kawaoka, and R. G. Webster. 1994. Potential for transmission of avian influenza viruses to pigs. Journal of General Virology 75:2183-2188.

Kou, Z., F. M. LeI, J. Yu, Z. J. FAN, Z. H. Yin, C. X. Jia, K. J. XIONG, Y. H. Sun, X. W. Zhang, X. M. Wu, AND OTHERS. 2005. New genotype of avian influenza H5N1 viruses isolated from tree sparrows in China. Journal of Virology 79:15460-15466.

Krauss, S., D. Walker, S. P. Pryor, L. Niles, L. Chenghong, V. S. Hinshaw, and R. G. Webster. 2004. Influenza A viruses of migrating wild aquatic birds in North America. Vector-Borne and Zoonotic Diseases 4:177-189.

Kuiken, T., G. Rimmelzwaan, D. van Riel, G. van Averongen, M. Batrs, R. Fouchier, And A.
Osterhal's. 2004. Avian H5N1 influenza in cats. Science 306:2 11

Kwox, Y.-K., S.-J. Joh, M.-C. Kin, Y.-J. LeE, J.-G. Choi, E.-K. Lee, S.-H. Wee, H.-W. Sexg, J.-H. Kwon, M.-I. Kt.vG, A.vD J.-H. KIn. 2005. Highly pathogenic avian influenza in magpies (Pica pica sericea) in South Korea. Journal of Wildlife Diseases 41:618-623.

Lai, A. C. K., And A. M. McPhillips. 1999. Isolation of avian influenza viruses in central Oklahoma. Journal of the Oklahoma State Medical Association 92:565-567.

LAMB, R. A. 1989. Genes and proteins of the influenza viruses. Pages 1-87 in The Influenza Viruses (R. M. Krug, Ed.). Plenum Press, New York.

Li, K. S., Y. Guan, J. Wang, G. J. D. Smith, K. M. XU, L. Duan, A. P. Rahardjo, P. Puthavathana, C. Buranathai, T. D. Nguyen, and others. 2004. Genesis of a highly pathogenic and potentially pandemic H5N1 influenza virus in eastern Asia. Nature 430:209-213.

Lin, Y. P., M. Shaw, V. Gregory, K. Cameron, W. Lim, A. Klimov, K. Subbarao, Y. Guan, S. Krauss, K. Shortridge, AND others. 2000. Avian-to-human transmission of H9N2 subtype influenza A viruses: Relationship between H9N2 and H5N1 human isolates. Proceedings of the National Academy of Sciences USA 97:9654-9658.

Lipatov, A. C., lu. A. Smirnov, N. V. Kaverin, and R. G. Webster. 2005. Evolution of avian influenza viruses H5N1 (1997-2004) in southern and south-eastern Asia. Voprosy Virusologii 50:11-17.

LiPKind, M. A., Y. Weisman, E. Shimmanter, AND D SHoHAM. 1979. Identification of avian influenza viruses isolated from wild Mallard ducks in Israel, Veterinary Record 105:558.

Lipkind, M. A., Y. Weisman, E. Shimmanter, D. Shoham, A. Douglas, and J. J. Skehel. 1980. Characterization of avian influenza viruses isolated in Israel in 1978-1979. Comparative Immunology, Microbiology and Infectious Diseases 3:185-192.

Liu, M., Y. Guan, M. Peiris, S. He, R. J. Webby, D. Perez, and R. G. Webster. 2003. The quest of influenza $\mathrm{A}$ viruses for new hosts. Avian Diseases 47:849-856.

Lit, J. H., K. Okazaki, A. Mweene, W. M. Shi, Q. M. Wu, J. L. Su, G. Z. Zhang, G. R. BaI, and H. KIDA. 2004. Genetic conservation of hemagglutinin gene of $\mathrm{H} 9$ influenza virus in chicken population in mainland China. Virus Genes 29: 329-334.

Liu, J., H. XIAO, F. Lei, Q. Zhu, K. QIN, X.-W. Zhang, X.-L. Zhang, D. ZhaO, G. Wang, Y. FENG, AND others. 2005. Highly pathogenic H5N1 influenza virus infection in migratory birds. Science 309:1206. 
Lr, H., A.ND A. E. Castro. 2004. Evaluation of the infectivity, length of infection, and immune response of a low-pathogenicity $\mathrm{H} 7 \mathrm{~N} 2$ avian influenza virus in specific-pathogen-free chickens. Avian Diseases 48:263-270.

Le, H., A. E. Castro, K. Pexinck, J. Lid, Q. Yang, P. Dunn, D. Weinstock, AND D. Henzler. 2003. Survival of avian influenza virus $\mathrm{H} 7 \mathrm{~N} 2$ in SPF chickens and their environments. Avian Diseases 47:1015-1021.

Mackenzie, J. S., D. Britten, V. S. Hinshaw, and J. I. WoOd. 1985. Isolation of avian influenza and paramyxoviruses from wild birds in western Australia. Pages 336-339 in Veterinary Viral Diseases: Their Significance in Southeast Asia and the Western Pacific (A. J. Della-Porta, Ed.). Academic Press, Sydney.

Mackenzie, J. S., E. C. Edwards, R. M. Holmes, AND V. S. Hinshaw. 1984. Isolation of orthoand paramyxoviruses from wild birds in western Australia, and the characterization of novel influenza A viruses. Australian Journal of Experimental Biology and Medical Sciences 62:89-99.

Makarova, N. A., N. V. Kaverin, S. Krauss, D. Senne, and R. G. Webster. 1999. Transmission of Eurasian avian $\mathrm{H} 2$ influenza virus to shorebirds in North America. Journal of General Virology 80:3167-3171.

Mase, M., K. Tsukamoto, T. Imada, K. Imai, N. Tanimura, K. Nakamura, Y. Yamamoto, T. Hitomi, T. KirA, T. NAKAI, AND Others. 2005. Characterization of $\mathrm{H} 5 \mathrm{~N} 1$ influenza $\mathrm{A}$ viruses isolated during the 2003-2004 influenza outbreaks in Japan. Virology 332:167-176.

Mastrosovich, M., N. Zhou, Y. Kawaoka, and R. Webster. 1999. The surface glycoproteins of H5 influenza viruses isolated from humans, chickens, and wild aquatic birds have distinguishable properties. Journal of Virology 73:1146-1155.

Mitnaul, L. J., M. N. Matrosovich, M. R. Castrucci, A. B. Tuzikov, N. V. Bovin, D. KoBASA, AND Y. KaWAOKA. 2000. Balanced hemagglutinin and neuraminidase activities are critical for efficient replication of influenza $A$ virus. Journal of Virology 74:6015-6020.

Monto, A. S. 2000. Epidemiology and virology of influenza illness. American Journal of Managed Care 6 (Supplement):255-264.

Nestorowicz, A., Y. KaWAoka, W. J. Bean, AND R. G. Webster. 1987. Molecular analysis of the hemagglutinin genes of Australian H7N7 influenza viruses: Role of passerine birds in maintenance or transmission? Virology 160:411-418.

Nettles, V. F., J. M. Wood, and R. G. Webster. 1985. Wildlife surveillance associated with an outbreak of lethal H5N2 avian influenza in domestic poultry. Avian Diseases 29:733-741.
Normile, D. 2005. Avian influenza: Potentially more lethal variant hits migratory birds in China. Science 309:231.

Olsex, C. W. 2002. The emergence of novel swine influenza viruses in North America. Virus Research 85:199-210.

OlSEN, C. W., S. CAREY, L. HINSHAW, AND A. I. Karasin. 2000. Virologic and serologic surveillance for human, swine and avian influenza virus infections among pigs in the north-central United States. Archives of Virology 145:1399-1419.

OtsuKI, K., K. YAMAZAKI, Y. KAWAOKA, AND M. Tsubokura. 1988. Intracerebral pathogenicity for chickens of avian influenza viruses isolated from free-living waterfowl in Japan. Veterinary Microbiology 18:357-362.

Panigrahy, B., D. A. Senne, J. C. Pedersen, A. L. Shafer, and J. E. Pearson. 1996. Susceptibility of pigeons to avian influenza. Avian Diseases 40:600-604.

Paniker, C. K. J., and C. M. G. Nair. 1970. Infection with A2 Hong Kong influenza virus in domestic cats. Bulletin of the World Health Organization 43:859-862.

Paniker, C. K. J., and C. M. G. Nair. 1972. Experimental infection of animals with influenza virus types A and B. Bulletin of the World Health Organization 47:461-463.

Peiris, J. S. M., Y. Guan, D. Markwell, P. Ghose, R. G. Webster, and K. F. Shortridge. 2001. Cocirculation of avian $\mathrm{H} 9 \mathrm{~N} 2$ and contemporary "human" H3N2 influenza A viruses in pigs in southeastern China: Potential for genetic reassortment? Journal of Virology 75:9679-9686.

Peiris, M., K. Y. Yuen, C. W. Leung, K. H. Chan, P. L. S. Ip, R. W. M. LaI, W. K. ORR, and K. F. SHortridge. 1999. Human infection with influenza H9N2. Lancet 354:916-917.

Perdue, M. L., M. Garcia, D. Senne, and M. Fraire. 1997. Virulence-associated sequence duplication at the hemagglutinin cleavage site of avian influenza viruses. Virus Research 49:173-186.

Perez, D. R., W. Lim, J. P. Seiler, G. Yi, M. Peiris, K. F. Shortridge, and R. G. Webster. 2003a. Role of quail in the interspecies transmission of $\mathrm{H} 9$ influenza A viruses: Molecular changes on HA that correspond to adaptation from ducks to chickens. Journal of Virology 77:3148-3156.

Perez, D. R., R. J. Webby, E. Hoffmann, and R. G. Webster. 2003b. Land-based birds as potential disseminators of avian/mammalian reassortant influenza A viruses. Avian Diseases 47: 1114-1117.

Perkins, L. E. L., and D. E. Swayne. 2002. Pathogenicity of a Hong Kong-origin H5N1 highly pathogenic avian influenza virus for emus, geese, ducks, and pigeons. Avian Diseases 46:53-63. 
Perolilis, I., ANo K. O'Riley. 2004. Detection of avian paramyxoviruses and influenza viruses amongst wild bird populations in Victoria. Australian Veterinary Journal 82:79-82.

Poss, P. E., D. A. Halvorson, a.ND D. KarLinakaran. 1981. Economic impact of avian influenza in domestic fowl in the United States. Pages 100-111 in Proceedings of the First International Symposium on Avian Influenza (B. A. Bankowski, Ed.). U.S. Animal Health Association, Richmond, Virginia.

Reid, A. H., T. G. Fanning, J. V. Hultin, and J. K. Taubenberger. 1999. Origin and evolution of the 1918 "Spanish" influenza virus hemagglutinin gene. Proceedings of the National Academy of Sciences USA 96:1651-1656.

Robson, J. M., M. W. Harrison, R. N. Wood, M. H. Tilse, A. B. Mckay, and T. R. Brodribi. 1993. Brucellosis: Re-emergence and changing epidemiology in Queensland. Medical Journal of Australia 159:153-158.

Romvary, I., J. Meszaros, K. Barb, and I. Matskasi. 1980. The role of wild birds in the spread of influenza viruses. Acta Microbiologica Academiae Scientiarum Hungaricae 27:269-277.

Rotr, R. 1992. The pathogenic determinant of influenza virus. Veterinary Microbiology 33: 303-310.

Roy, G., J. Burton, J. Lecomte, and A. Boudreault. 1983. Role of passerine birds in the ecology of influenza viruses. Revue Canandienne de Biologie Expérimentale 42:73-81.

Schafer, J. R., Y. Kawaoka, W. J. Bean, J. Suss, D. Senne, R. G. Webster. 1993. Origin of the pandemic $1957 \mathrm{H} 2$ influenza A virus and the persistence of its possible progenitors in the avian reservoir. Virology 194:781-788.

Scholtissek, C., I. Koennecke, and R. Rotr. 1978. Host-range recombinants of fowl plague (influenza A) virus. Virology 91:79-85

Senne, D. A., B. Panigrahy, Y. Kawaoka, J. E. Pearson, J. Suss, M. Lipkind, H. Kida, and R. G. WeBSTER. 1996. Survey of the hemagglutinin (HA) cleavage site sequence of $\mathrm{H} 5$ and $\mathrm{H} 7$ avian influenza viruses: Amino acid sequence at the HA cleavage site as a marker of pathogenicity potential. Avian Diseases 40:425-437.

Senne, D. A., B. Panigrahy, and R. L. Morgan. 1994. Effect of composting poultry carcasses on survival of exotic avian viruses: Highly pathogenic avian influenza (HPAI) virus and adenovirus of egg drop syndrome-76. Avian Diseases 38:733-737.

Sharp, G. B., Y. KaWAOKa, S. M. Wright, B. Turner, V. Hinshiw, and R. G. Webster. 1993. Wild ducks are the reservoir for only a limited number of influenza A subtypes. Epidemiology and Infection 110:161-176.
Shortridge, K. F., N. N. Zhot, Y. Guan, P. GaO, T. Ito, Y. KawaOaDa, S. Kodihalli, S. Kralss, D. Markweli, K. G. Murti, and others. 1998. Characterization of avian $\mathrm{H} 5 \mathrm{~N} 1$ influenza viruses from poultry in Hong Kong. Virology 252:331-342.

Siemons, R. D., Aind D. E. Swayne. 1995. Tissue tropism and replicative properties of waterfowlorigin influenza viruses in chickens. Avian Diseases 39:521-527.

SNaCKen, R., A.P. Kendal, L. R. HaAheim, and J. M. Wood. 1999. The next influenza pandemic: Lessons from Hong Kong, 1997. Emerging Infectious Diseases 5:195-203.

Stallknecht, D. E. 1998. Ecology and epidemiology of avian influenza viruses in wild bird populations. Pages 61-69 in Proceedings of the Fourth International Symposium on Avian Influenza (D. F. Swayne and R. D. Slemons, Eds.). Animal Health Association, Athens, Georgia.

Stallknecht, D. E., M. T. Kearney, S. M. Shane, and P. J. ZWANk. 1990a. Effects of $\mathrm{pH}$, temperature, and salinity on persistence of avian influenza viruses in water. Avian Diseases 34:412-418.

Stallknecht, D. E., and S. M. Shane. 1988. Host range of avian influenza virus in free-living birds. Veterinary Research Communications 12:125-141.

Stallknecht, D. E., S. M. Shane, M. T. Kearney, and P. J. Zwank. 1990b. Persistence of avian influenza viruses in water. Avian Diseases 34: 406-411.

Stallknecht, D. E., S. M. Shane, M. T. Kearney, AND P. J. Zwank. 1990c. Avian influenza viruses from migratory and resident ducks of coastal Louisiana. Avian Diseases 34:398-405.

Suarez, D. L. 2000. Evolution of avian influenza viruses. Veterinary Microbiology 74:15-27.

Suarez, D. L., D. A. Senne, J. Banks, I. H. Brown, S. C. Essen, C. W. Lee, R. J. Manvell, C. MathieuBenson, V. Moreno, J. C. Pedersen, and others. 2004. Recombination resulting in virulence shift in avian influenza outbreak, Chile. Emerging Infectious Diseases 10:693-699.

Swayne, D. E., and D. L. Suarez. 2000. Highly pathogenic avian influenza. Revue Scientifique et Technique 19:463-482.

Tracey, J. P., R. Woods, D. Roshier, P. West, and G. R. SAunders. 2004. The role of wild birds in the transmission of avian influenza for Australia: An ecological perspective. Emu 104: 109-124.

Van Borm, S., I. Thomas, G. Hanquet, B. Lambrecht, M. Boschmans, G. Dupont, M. Decaestecker, R. SNaCKen, and T. vaN DEN Berg. 2005. Highly pathogenic $\mathrm{H} 5 \mathrm{~N} 1$ influenza virus in smuggled Thai eagles, Belgium. Emerging Infectious Diseases 11:702-705. 
Villarreal-Chavez, C., and E. Rivera-Cruz. 2003. An update on avian influenza in Mexico. Avian Diseases 47:1002-1005.

Webby, R. J., D. R. Perez, J. S. Colemar, Y. Guar, J. H. KNight, E. A. Govorkova, L. R. MCClaINMoss, J. S. Peiris, J. E. Rehg, E. I. Tuomanen, A.vo R. G. Webster. 2004. Responsiveness to a pandemic alert: Use of reverse genetics for rapid development of influenza vaccines. Lancet 363:1099-1103.

Webby, R. J., S. L. Swenson, S. L. Krauss, P. J. Gerrish, S. M. Goyal, ANd R. G. Webster. 2000. Evolution of swine H3N2 influenza viruses in the United States. Journal of Virology 74:8243-8251.

Webster, R. G., W. J. Bean, O. T. Gorman, T. M. Chambers, and Y. Kawaoka. 1992. Evolution and ecology of influenza A viruses. Microbiological Reviews 56:152-179.

Webster, R. G., V. S. Hinshaw, W. J. Bean, JR., B. Turner, AND K. F. Shortridge. 1977. Influenza viruses from avian and porcine sources and their possible role in the origin of human pandemic strains. Developments in Biological Standardization 39:461-468.

Weiss, R. A., and A. J. McMichael. 2004. Social and environmental risk factors in the emer- gence of infectious diseases. Nature Medicine 10 (Supplement):70-76.

WestBiRY, H. A. 1997. History of high pathogenic avian influenza in Australia and the $\mathrm{H} 7 \mathrm{~N} 3$ outbreak (1995). Pages 23-30 in Proceedings of the Fourth International Symposium on Avian Influenza. (D. E. Swayne and R. D. Slemons, Eds.). U.S. Animal Health Association, Athens, Georgia.

Widjaja, L., S. L. Krauss, R. J. Webby, T. XIF, and R. G. Webster. 2004. Matrix gene of influenza A viruses isolated from wild aquatic birds: Ecology and emergence of influenza A viruses. Journal of Virology 78:8771-8779.

Wright, S. M., Y. Kawaoka, G. B. Sharp, D. A. Senne, and R. G. Webster. 1992. Interspecies transmission and reassortment of influenza A viruses in pigs and turkeys in the United States. American Journal of Epidemiology 136: 488-497.

Zhou, N. N., D. A. Senne, J. S. Landgraf, S. L. SWENSON, G. ERICKSON, K. Rossow, L. LiU, K. Yoon, S. Krauss, and R. G. Webster. 1999. Genetic reassortment of avian, swine, and human influenza A viruses in American pigs. Journal of Virology 73:8851-8856. 